Nélio Alessandro de Jesus Oliveira

Estudo molecular das craniossinostoses sindrômicas:

Crouzon, Pfeiffer e Saethre-Chotzen

\author{
Instituto de Biociências \\ Universidade de São Paulo \\ São Paulo
}


Nélio Alessandro de Jesus Oliveira

\section{Estudo molecular das craniossinostoses sindrômicas: Crouzon, Pfeiffer e Saethre-Chotzen}

Dissertação, apresentada ao Instituto de Biociências da Universidade de São Paulo, para obtenção do Título de Mestre em Ciências, na Área de Biologia/Genética

Orientadora: Profa. Dra. Maria Rita dos Santos e Passos Bueno

São Paulo 
2006 


\section{Ficha Catalográfica}

Oliveira, Nélio Alessandro de Jesus

Estudo molecular das

craniossinostoses sindrômicas: Crouzon,

Pfeiffer e Saethre-Chotzen.

Número de páginas

Dissertação (Mestrado) - Instituto de Biociências da Universidade de São Paulo. Departamento de Genética e Biologia Evolutiva.

1. Palavra-Chave Craniossinostose I. Universidade de São Paulo. Instituto de Biociências. Departamento de Genética e Biologia Evolutiva.

\section{Comissão Julgadora:}

$\operatorname{Prof(a).~Dr(a).~}$

$\operatorname{Prof}(a) \cdot \operatorname{Dr}(a)$
Prof(a). Dr(a).

$\operatorname{Prof}(a) \cdot \operatorname{Dr}(a)$. 


\section{Dedicatória}

Aos meus pais, pelo amor e carinho, pelo incentivo. Sinto-me honrado por ser filho de vocês. 
"Devemos fazer da queda um novo passo de dança. Do medo uma ponte. Do sonho uma procura. Da procura um encontro.” (Fernando Sabino)

"Another turning point
a fork stuck in the road
Time grabs you by the wrist
directs you where to go
So make the best of this test
and don't ask why
It's not a question
but a lesson learned in time"

(Billie Joe Armstrong)

Aos pacientes e familiares, sem os quais este trabalho não poderia ter sido realizado.

À Dra. Maria Rita Passos-Bueno, pela oportunidade, orientação, confiança e amizade tão importantes para a minha formação profissional e humana, agradeço em especial.

Ao Dr. Luís Alonso Garcia pela colaboração na avaliação clínica de nossos pacientes, pela amizade e incentivo.

A Dra Mary Cleide Sogayar pela colaboração nos experimentos de clonagem.

Ao amigo Antero F. Macedo pela ajuda na realização dos estudos funcionais e pelo apoio incondicional.

Aos grandes amigos: Agnes, Andréa, Antônia, Bia, Carlos, Cibele, Daniela, Erika Yeh, Erika Kague, Fernanda, Flávia,Guilherme, Gustavo, Karina, Kelly, Lúcia, Marta, Mayara, Miguel, Monize, Oscar, Roberto, Roseli e Viviane pelo carinho, companherismo e valiosa amizade em todos os momentos.

À Constância, pela paciência, amizade e cuidados de "mãe".

Aos funcionários do Genoma: Camila, Kátia, Lílian, Lucas, Martha, Miguel, Roberto, Valter e Vanessa por todo apoio e amizade em todos os momentos.

Ao meu amado irmão, Diego pelo carinho, amizade incondicional, apoio, torcida, e por acreditar neste sonho.

Aos Amigos, Adriano, Matheus e Paulo, pelas discussões em músicas, filmes, física quântica, cadeias de markov, linux e demais histórias.

$\mathrm{E}$ a todos aqueles que por ventura não foram mencionados aqui, mais que contribuiram para este sonho, meu muitíssimo obrigado. 
Esta tese de doutorado foi desenvolvido entre julho/2004 a julho/2006 no Laboratório de Genética do Desenvolvimento Humano, integrante do Centro de Estudos do Genoma Humano do Instituto de Biosciências da Universidade de São Paulo (USP), São Paulo, SP.

A apresentação deste trabalho é uma proposta para o Programa de PósGraduação em Biologia/genética como um novo molde de tese de mestrado que está sendo adotado por muitos institutos da USP e outras universidades. Os resultados experimentais obtidos neste projeto são apresentados em capítulos como eles foram, ou serão, submetidos à publicação, inclusive em sua redação original na língua inglesa. Somente o capítulo III está redigido em inglês sendo que os estão redigidos em português.

Todas as referências bibliográficas desta tese foram agrupadas no capítulo IX, com exceção das referências relativas aos artigos científicos, que se encontram no final de cada respectivo capítulo. Na elaboração das referências não foi seguida a normatização NBR6023 - ABNT pois a utilização de letras maiúsculas dificulta a leitura do texto. 


\section{Índice}

Resumo 01

Abstract _ 03

Capítulo 1- Introdução geral e objetivos _ـ 04

$\begin{array}{ll}\text { 1.1-Introdução Craniossinostoses__ } & 05\end{array}$

$\begin{array}{ll}\text { 1.1.2- Craniossinostoses Sindrômicas __ } & 08\end{array}$

1.2- Aspectos clínicos das síndromes de craniossinostoses

$\begin{array}{ll}\text { mais comuns } & 10\end{array}$

1.2.1-Síndrome de Apert — 10

$\begin{array}{lr}\text { 1.2.2-Síndrome de Crouzon } & 10\end{array}$

$\begin{array}{ll}\text { 1.2.3 - Síndrome de Pfeiffer } & 11\end{array}$

1.2.4- Síndrome de Muenke __ 11

1.2.5- Síndrome de Saethre-Chotzen ___ 12

1.3- Mecanismos moleculares relacionados às síndromes de

Apert, Crouzon, Pfeiffer, Muenke e Saethre-Chotzen ___ 12

1.3.1- Síndrome de Apert _ـ 12

1.3.2- Síndrome de Crouzon __ 13

1.3.3- Síndrome de Pfeiffer _ 13

1.3.4- Síndrome de Muenke _ 14

$\begin{array}{ll}\text { 1.3.5- Síndrome de Saethre-Chotzen __ } & 14\end{array}$

1.4.1 -Fatores de crescimentos de Fibroblastos e receptores

$\begin{array}{ll}\text { de fatores de crescimento de fibroblasto __ } 15 & 15\end{array}$

1.4.2- TWIST 1 e Região 5'a montante do TWIST1 ___ 17

2- Objetivos do Projeto

2.1- Objetivos gerais

2.2- Objetivos específicos 

Capítulo 2- Casuística e Métodos 20

1.1- Seleção de Pacientes e Controles 21

1.2- Coleta de sangue periférico e extração de DNA 21

$1.3-\mathrm{PCR}$ 22

1.4 - Método de dHPLC 24

1.5 - Sequênciamento automático 25

1.6-Triagem de mutação nos genes FGFR1, FGFR2, FGFR3 e TWIST1 26

2. 1 Análise da variação na funcionalidade do promotor em relação à mutação encontrada 27

Capítulo 3- Further evidence of association between mutations in FGFR2 and syndromic craniosynostosis with sacrococcygeal eversion 29

Capítulo 4- Análise dos genes FGF3 e FGF4 em pacientes

Com craniossinostose sindrômica 42

Capítulo 5- Análise do gene TWIST1 em pacientes com

síndrome de Saethre-Chotzen: descrição de três novas mutações 49

Capítulo 6- Discussão e Conclusões 63

Capítulo 7- Referências 67

Anexo 1 73

Parte1. Certificado de aprovação no comitê de ética 73

Parte 2. Dados clínicos de todos os pacientes com craniossinostose sindrômica estudados durante o período desta dissertação 74

Parte 3. Termo de consentimento e livre esclarecido 76

Anexo 2 83

Condições de PCR 77 
As craniossinostoses, resultantes da fusão precoce de uma ou mais suturas cranianas, representam um grupo heterogêneo de doenças que ocorre aproximadamente em 1:2000 nascidos vivos. Caracterizam-se por grande variabilidade clínica e heterogeneidade genética, com raras exceções como a Síndrome de Apert. As craniossinostoses podem ser classificadas em não sindrômicas, quando o único problema do paciente é a fusão precoce da sutura, e sindrômica quando outros problemas estão presentes. Dentre as craniossinostoses sindrômicas, as mais comuns são a Síndrome de Crouzon, Pfeiffer e Apert. O diagnóstico diferencial entre estas 3 síndromes é dado principalmente pelo grau de comprometimento dos membros, sendo que na Síndrome de Crouzon, a mais leve, não há comprometimento de membros, enquanto que na Síndrome de Apert, a mais grave, os membros estão sempre comprometidos. O mecanismo mutacional é identificado em aproximadamente $58 \%$ dos pacientes Síndrome de Crouzon, sendo que o gene FGFR2 corresponde à $48 \%$ desse total e mutações nos genes TWIST1 e FGFR3 correspondem aos 10\% dos casos restantes. Assim sendo, cerca de $42 \%$ dos casos com características clínicas compatíveis com a Síndrome de Crouzon, não apresentam mutações em nenhum destes três genes, e, portanto, mutações em outros genes podem ser responsáveis por este quadro clínico.Aproximadamente $45 \%$ dos casos de Pfeiffer não estão relacionadas a mutações nos genes FGFR1 e FGFR2, indicando que outros genes também podem estar envolvidos. Por outro lado, todos os casos de Síndrome de Apert são causados por mutações no gene FGFR2. As mutações em FGFR2 apresentam uma correlação parcial entre genótipo e fenótipo, contudo, casos graves, como aqueles com Síndrome de Pfeiffer tipo II ou III são ainda muito pouco caracterizados. Experimentos utilizando-se inserção retroviral em camundongos levaram a identificação de um fenótipo semelhante à síndrome de Crouzon, o qual parece ter sido causado por um aumento da expressão do produto dos genes FGF3 e FGF4. Além disso, a implantação de beads contendo Fgf4 em crânios de camundongos neonatais acelerou o fechamento das suturas, em decorrência do aumento da proliferação e diferenciação dos osteoblastos. Assim sendo, é possível que mutações nos genes FGF3 e FGF4 possam causar um fenótipo semelhante à Síndrome de Crouzon ou craniossinostoses sindrômicas.A identificação de mutações patogênicas do gene TWIST1 em pacientes com síndrome de Saethre-Chotzen, 
tem colaborado para a caracterização de domínios funcionais da proteína codificada por este gene. Até o momento, estas mutações, que podem ser do tipo substituição de aminoácido ou que criam códigos de parada prematura, levam a perda da função da proteína por diferentes processos, e, portanto, o mecanismo responsável pela síndrome é o da haploinsuficiência. Até o momento, apenas mutações em regiões codificadoras têm sido associadas à doença e há muita pouca informação a respeito do efeito de mutações na região reguladora do gene TWIST1.Em vista do exposto acima, julgamos importante testarmos os genes FGF3 e FGF4 em pacientes com Síndrome de Crouzon e craniossinostose sindrômica sem mutações nos genes candidatos, com o objetivo de verificar se mutações nesses possam ser responsáveis pelo fenótipo dos pacientes. Julgamos também importante verificar se uma paciente com Pfeiffer tipo 3 era portadora de mutação patogênica no gene FGFR2 bem como identificar mutações em 7 pacientes com a síndrome de Saethre-Chotzen. Ainda, realizamos estudos funcionais para verificar se uma mutação nova localizada em região reguladora do gene TWIST1 é responsável pelo fenótipo da paciente. 
Craniosynostosis, defined as the premature fusion of one or more cranial suture, are a very heterogeneous group of disorders, with an occurrence of about 1: 2000 live births. Except for rare syndromes, such as Apert, most of the cranioysnostotic conditions are characterized by wide clinical variability and genetic heterogeneity. Craniosynostosis can be classified into non syndromic forms - premature suture fusion is the only clinical alteration, and syndromic ones - premature cranial suture fusion associated with other anomalies. Apert, Pfeiffer, Crouzon and Saethre-Chotzen are the most common syndromic forms of craniosynostosis. The mutational mechanism is identified in approximately $58 \%$ of patients with Crouzon syndrome: FGFR2 mutations account for most of the cases (more than 80\%) while mutations in TWIST1 and FGFR3 causes the remaining of them. Therefore, about $42 \%$ of the cases with clinical characteristics of Crouzon syndrome do not harbor mutations in any of these 3 genes and other mutational mechanisms might be responsible for the phenotype. Approximately $45 \%$ of Pfeiffer syndrome cases is not caused by mutations in the FGFR1 or FGFR2 genes, thus also suggesting genetic heterogeneity for this phenotype. On the other hand, all cases with Apert syndrome are caused by specific mutations in FGFR2. FGFR2 mutations show a partial genotype-phenotype correlation; however, severe cases, such as Pfeiffer types II and III are still very poorly characterized. Retroviral insertion experiments in mouse lead to the identification of animals with a phenotype that resembles Crouzon syndrome. It was suggested that this phenotype was caused by upregulation of the Fgf3 and Fgf4 genes as a consequence of the insertion of the retrovirus between these 2 genes. In addition, implantation of beads with Fgf4 in the cranium of neonatal mice has increased the fusion of the cranium sutures . Therefore, it is possible that gain of function mutations in the FGF3 e FGF4 genes might lead to Crouzon or syndromic craniosynostosis. Characterization of pathogenic mutations in the TWIST1 gene among patients with Saethre-Chotzen syndrome has contributed for a better understanding of the protein domains of the corresponding protein. These mutations, which are missense or null, cause loss of function of the protein and haploinsufficiency of the TWIST1 gene has been postulated as the mechanism model for Saethre-Chotzen syndrome.Up to now, only pathogenic mutations in coding regions have been associated with the disease and there is very little information about the effect of mutations on the regulatory regions of the TWIST1 gene 
on the phenotype.Considering the above information, the aims of the present work were: a) verify if mutations in FGF3 and FGF4 can cause craniosynostosis; b) verify if the severe phenotype in a patient Pfeiffer type 3 is due to a specific mutation in FGFR2; c) identify mutations in 7 patients with Saethre-Chotzen syndrome; d) verify if a mutation in the regulatory region of the TWIST1 gene can cause craniosynostosis. 


\section{I.1 - Craniossinostoses}

\section{1) Craniossinostoses:}

O crânio de vertebrados é composto por estruturas originadas do neurocrânio que envolvem e protegem o encéfalo, e pelo viscerocrânio, que suporta as funções de respiração e alimentação e forma a face em mamíferos (revisão em Morris-Kay \& Wilkie, 2005). A formação dessas estruturas é regulada por fatores de crescimentos sistêmicos e locais que levam a uma precisa reunião de elementos ósseos e cartilaginosos que protegem o encéfalo (Bodo et al., 1999; Holleville et al., 2003). Perturbações genéticas ou ambientais deste complexo sistema podem levar a fusão prematura das suturas cranianas (Warren \& Longaker, 2001). Essa fusão prematura de uma ou mais suturas cranianas recebe a denominação de craniossinostose (revisão em Passos-Bueno et al., 1999; Wilkie \& Morris-Kay, 2001).

As Craniossinostoses representam um grupo heterogêneo de desordens que ocorre aproximadamente em 1:2000 nascidos vivos. Clinicamente são o grupo de doenças mais importantes que acomete o desenvolvimento da caixa craniana humana (Warren \& Longaker, 2001; Wilkie \& Morris-Kay 2001).

Este crescimento anormal da caixa craniana pode estar associado ao aumento da pressão intracraniana, comprometendo as perfusões encefálicas, obstruindo as vias aéreas, podendo haver ainda comprometimento de visão e audição, dificuldades de aprendizagem e deformidades estéticas significativamente graves (Wilkie \& Morris-Kay,2001,Cohen, 2004). O único tratamento disponível para indivíduos com craniossinostose é o tratamento cirúrgico, que pode requerer mais de uma intervenção e implica no uso de múltiplos procedimentos (Johnson, 2003).

Podem estar comprometidas as suturas coronais, metópica, lambdóide e sagital, sendo que uma ou mais suturas podem ser afetadas num indivíduo (Chan \& Thorogood,1999; Warren \& Longaker, 2001). As craniossinostoses são 
geralmente classificadas de acordo com o formato que o crânio adquire que, por sua vez, é decorrente da sutura envolvida, da época que ocorre a sinostose e da fusão total ou parcial dos ossos (Cohen Jr., 2000.,Cohen Jr., 2004). Por exemplo, a braquicefalia, que apresenta um achatamento da região posterior do crânio é o resultado da fusão da sutura coronal (Cohen Jr.,2000, Cohen Jr., 2004)(Tabela $1)$.

As craniossinostoses podem ser classificadas em não sindrômicas, quando o paciente apresenta apenas comprometimento das suturas, sem comprometimento de outros órgãos ou tecidos; e sindrômicas, quando acompanhadas de outras anomalias tais como: deformidades faciais, retardamento mental e comumente problemas na formação de membros (Fragale et al., 1999; Warren et al., 2003; Cohen Jr.,2004).

Tabela 1 - Classificação das craniossinostes em relação à sutura envolvida

\begin{tabular}{ccc}
\multicolumn{1}{c}{ Sutura } & Classificação \\
Sagital & Escafocefalia \\
Uma coronal & Plagiocefalia \\
As duas coronais & Braquicefalia \\
Metópica & Trigonocefalia
\end{tabular}


Apesar das craniossinostoses não sindrômicas corresponderem à maioria das formas, existem mais de 150 síndromes descritas (Warren \&Longaker, 2001). O padrão de herança autossômico dominante vem sendo descrito como o tipo de herança mais freqüentemente relacionada as craniossinostoses sindrômicas (Cohen Jr., 2004). Dentre as craniossinostoses sindrômicas, as Síndromes de Apert, de Crouzon, Pfeiffer, Muenke e Saethre-Chotzen são as mais comuns (revisão Passos-Bueno et al. 1999).

Os genes conhecidos envolvidos com craniossinostoses síndrômicas são os receptores de fatores de crescimento de fibroblastos (FGFR1, FGFR2 e FGFR3) e os fatores de transcrição MSX2 e TWIST1 e o receptor de epinefrina EFBN-1 (tabela 2) (Nacamuli et al., 2002; Morris-Kay \& Wilkie, 2005).

Inicialmente iremos falar sobre os aspectos clínicos das formas mais comuns de craniossinostoses sindrômicas. Posteriormente iremos abordar os aspectos moleculares ligados a esse grupo de patologia. 
Tabela 2 - Genes envolvidos com Craniossinostoses

\begin{tabular}{ccll} 
GENE & LOCALIZAÇÃo & FUNÇÃo & Fenótipo na presença de mutações \\
\hline EFBN-1 & Xq13.1 & -Codifica um ligante epinefrina B que & Sinostose de suturas coronais (uma ou \\
& se liga nos receptores Eph tirosina & ambas), hipertelorismo, sindactilia \\
& quinase & cutânea parcial, fenda de lábio ou \\
& & palato, agenesia parcial ou completa do \\
& & corpo caloso.
\end{tabular}
$\begin{array}{lll}\text { FGFR1 } & \text { 8p 11.2-p11.1 } & \begin{array}{l}\text {-Receptor de fatores de crescimento de } \\ \text { fibroblastos }\end{array}\end{array}$

Receptor de fatores de crescimento de fibroblastos

Receptor de fatores de crescimento de fibroblastos

-Fator de transcrição

-Fator de transcrição
Craniossinostose, hipoplasia da face média, braquidactilia, digitos dos pés aumentados e sindactilia variável.

Fusão de uma mais sutura, hipertelorismo, proptose ocular, comprometimento de membros (exceção Síndrome de Couzon), dentre outros.

Fusão precoce de um ou ambas coronais, mocrocefalia, hipoplaisa do terço médio da face, proptose ocular, sindactilia de mãos e pés variável.

Turribraquicefalia sindactilia de membros ausente.
Braquicefalia geralmente com sinostose da sutura coronal, assimetria facial, hipertelorismo, proptose ocular desvio de septo nasal, hipoplasia maxilar, comprometimento auditivo, alteração dos membros como braquidactilia, primeiros dígitos do pé aumentados, e sindactilia cutânea; e em alguns casos um leve retardo mental. 


\subsection{Aspectors clínicos das síndromes de craniossinostoses mais comuns}

\subsubsection{Síndrome de Apert}

A síndrome de Apert (AS) é uma das craniossinostoses mais graves, com incidência de 1:64000 nascimentos e herança autossômica dominante, o que representa cerca de 4,5\% de todas as craniossinostoses (Cohen Jr. \& Kreiborg, 1992, OMIM \#101200).

Esta síndrome é caracterizada pela fusão prematura das suturas coronais, anomalias craniofaciais, sindactilia simétrica das mãos e dos pés e malformações no sistema nervoso central, hipoplasia do terço médio da face (Cohen Jr. 2000) Outras anomalias podem estar presentes em indivíduos portadores de Apert, tais quais: malformações cardiovasculares (presentes em 10\% dos casos), e genitourinárias $(9,6 \%)$, anomalias no sistema respiratório (1,5\%) e gastrointestinal (1,5\%) (Cohen Jr. 2000, Cohen Jr. 2004).

A maior parte dos casos dessa síndrome é esporádica. A baixa proporção de casos famíliais se deve ao baixo valor adaptativo apresentado pelos pacientes uma vez que a gravidade do fenótipo impede esses de terem um padrão de vida normal (Cohen Jr.2004).

\subsubsection{Síndrome de Crouzon}

A Síndrome de Crouzon (CS), que foi descrita em 1912 pelo neurologista francês Octave Crouzon, é caracterizada clinicamente pela fusão prematura de uma ou mais suturas sendo a coronal a mais freqüente, seguida pela sagital e lambdóide. Nesta síndrome ainda ocorre hipoplasia da face média e órbitas rasas, originando proptose ocular, anormalidades do sistema nervoso central em função da estenose, não ocorrendo alterações dos membros superiores e inferiores (Cohen Jr. 2000; Baroni et al., 2002; Cohen Jr.,2004).

As alterações craniofaciais são semelhantes às que ocorrem nas síndromes de Pfeiffer e Apert, contudo em Peiffer há um leve comprometimento de membros e em Apert há um forte comprometimento de membros resultando 
em sindactilia e freqüentemente grave retardo mental, sendo este um dos principais diagnósticos diferencias utlizados na classificação dos pacientes (Cohen Jr. 2000; Baroni et al., 2002; Cohen Jr.,2004).

O padrão de herança é o autossômico dominante, sendo a maior parte dos casos decorrentes de mutações "de novo", (revisão em Passos-Bueno et al., 1999; Cohen Jr., 2000, Scheid et al., 2002). A penetrância é completa e há grande variabilidade clínica. Ao contrário do observado nas famílias de pacientes de Apert, na Síndrome de Crouzon os casos familiais são mais comuns, uma vez que o fenótipo é mais leve, o que, na maior parte das vezes, é compatível com a vida normal.

\subsubsection{Síndrome de Pfeiffer}

A Síndrome de Pfeiffer (PS), também uma doença autosômica dominante, se caracateriza por craniossinostose, hipoplasia da face média, braquidactilia, digitos dos pés aumentados e sindactilia variável (Tartaglia et al., 1997, Kress et al., 2000, Cohen, 2004).

Clinicamente, a Síndrome de Pfeiffer é dividida em três tipos (Cohen 1993; Cohen 2004). A forma clássica da Síndrome de Pfeiffer ou Síndrome de Pfeiffer tipo I (PSI) é a mais comum delas e é compatível com inteligência e vida normal na maioria dos casos. A Síndrome de Pfeiffer tipo 2 (PSII) é caracterizada pela presence do crânio em forma de trevo, proptose ocular grave comprometimento do sistema nervosa central (SNC), anquilosia de cotovelos, dedos da mão aumentados (Cohen 1993). Finalmente, a Síndrome de Pfeiffer tipo 3 (PSIII) é similar ao tipo dois, mas não possui o crânio com o formato de trevo.

\subsection{4) Síndrome de Muenke}

A Síndrome de Muenke caracteriza-se por uma grande variabilidade fenotípica. Nesta síndrome há comprometimento de uma ou ambas coronais. Dificuldades auditivas e de aprendizado também podem estar associadas (Cohen Jr.2000, RannanEliya et al. 2004). Como as demais craniossinostoses sindrômicas possui o padrão de 
herança autossômico dominante (Bellus et al. 1996, Cohen Jr. 2000). Sua prevalência é estimada em 1 em 30000 casos, correspondendo a aproximadamente $8 \%$ das craniossinostoses (Rannan-Eliya et al. 2004). 


\subsection{5) Síndrome de Saethre-Chotzen}

A síndrome de Saethre-Chotzen é caracterizada clinicamente por braquicefalia ou acrocefalia geralmente com sinostose da sutura coronal com uma prevalência de 1:25000. Observa-se ainda, assimetria facial, hipertelorismo, proptose ocular, desvio de septo nasal, hipoplasia maxilar, comprometimento auditivo, alteração dos membros como braquidactilia, primeiros dígitos do pé aumentados, e sindactilia cutânea; e em alguns casos um leve retardo mental (Bourgeois et al. 1998; Cohen, 2004). O padrão de herança é o autossômico dominante com alta penetrância.

A variabilidade clínica é bastante grande, na mesma genealogia ou não. Indivíduos que não apresentam alterações de membros, algumas vezes são diagnosticados como portadores da síndrome de Crouzon ou com alguma outra craniossinostose (Bourgeois et al. 1998).

\subsection{Mecanismos moleculares relacionados às síndromes de Apert, Crouzon, Pfeiffer, Muenke e Saethre-Chotzen}

\subsubsection{Síndrome de Apert}

Como mencionado anteriormente, a síndrome de Apert também se caracteriza por não ter heterogeneidade genética; sendo que todas mutações conhecidas nessa síndrome estão relacionadas ao gene FGFR2. Duas mutações, que correspondem a 99\% dos casos desta síndrome, foram encontradas na região de ligação entre as alças Ig-like II e Ig-like III da proteína FGFR2 (Oldridge et al. 1997, Anderson et al. 1998, Cohen Jr. 2000). São elas c.755C $\rightarrow \mathrm{G}$, resultando na substituição p.Ser 252 Trp na proteína e c.758C $\rightarrow \mathrm{G}$, resultando em p.Pro253Arg. A primeira é mais comum e está presente em cerca de $2 / 3$ dos pacientes, sendo mais freqüentemente associada à fenda palatina. A mutação p.Pro253Arg está presente em 1/3 dos pacientes, sendo freqüentemente associada a sindactilia grave (Bodo et al.1997Cohen Jr. 2004). 


\subsubsection{Síndrome de Crouzon}

A grande maioria dos casos de Síndrome de Crouzon é devido a mutações no gene FGFR2, localizadas preferencialmente no terceiro domínio semelhante à imunoglobulina. Há mais de 50 mutações neste gene sendo que a maioria é resultante de substituições de aminoácidos (missense) (Cohen Jr., 2000; Kan et al., 2002). Uma mesma mutação que leva a um fenótipo de Crouzon pode levar também a um fenótipo da Síndrome de Pfeiffer, como foi observado para as seguintes alterações: Y105C, S267P, F276V, C342W, C342Y do FGFR2. O mecanismo no qual uma mesma mutação causa fenótipos distintos ainda precisa ser elucidado. Também foram localizadas mutações nos genes FGFR3 e TWIST1 associadas ao fenótipo de Crouzon.

No gene TWIST1 foi identificada uma única substituição de adenina A por $\mathrm{G}$ guanina na posição c.340, resultando na troca de aminoácido asparagina por aspartato na posição 144 da proteína (Cohen Jr. 2004). No gene FGFR3 temos a mutação P250R que está ligada a alguns casos diagnosticados como portadores da Síndrome de Crouzon (Cohen Jr.2004). A proporção de pacientes com Síndrome de Crouzon com mutações nos genes TWIST1 e FGFR3 é baixa, correspondendo a $10 \%$ dos casos, enquanto que aproximadamente $48 \%$ dos pacientes possuem mutação em FGFR2 (Cohen Jr. 2004).

Assim sendo, cerca de $40 \%$ dos casos com características clínicas compatíveis com a Síndrome de Crouzon, não apresentam mutações em nenhum destes três genes e, portanto, mutações em outros genes podem ser responsáveis por este quadro clínico.

\subsubsection{Síndrome de Pfeiffer}

Mutações em FGFR1 e FGFR2 estão associadas a maior parte das formas da Síndrome de Pfeiffer (Passos-Bueno et al. 1999, Wilkie, 2005). Há uma grande sobreposição de sintomas entre as síndromes de Crouzon e Pfeiffer, e o diagnóstico clínico diferencial é dado principalmente pelo grau de comprometimento dos membros, pois estes estão normais na Síndrome de Crouzon, como mencionado anteriormente (Wilkie et al. 2005, Lajeunie et al. 2006). 
As formas graves de Pfeiffer tipo II e III tem sido relacionadas a mutações específicas (p.Ser351Cys, p.Trp 290Cys,p.Cys342Arg). Estas formas se caracterizam por terem um forte comprometimento visceral. Poucos casos destas formas graves estão relatados na literatura, o que dificulta no entendimento do mecanismo gerador dessas formas graves (Wilkie, 2005).

Ainda, mutações nos genes FGFR1 e FGFR2 não explicam todos os casos de Síndrome de Pfeiffer sugerindo, portanto, que há outros genes que quando mutados causam esta síndrome.

\subsubsection{Síndrome de Muenke}

A mutação p.Pro250Arg no gene FGFR3 está associada a esta doença (Bellus et al. 1996). Pacientes com quadro clínico de Saethre-Chotzen e Pfeiffer que não apresentam mutação nos genes TWIST1, FGFR1 e FGFR2 respectivamente, geralmente são testados para essa síndrome, uma vez que há sobreposição de sintomas entre elas (Cohen Jr.2000). Ainda, casos de craniossinostose não sindrômica podem ser decorrentes desta mutação.

\subsubsection{Síndrome de Saethre-Chotzen}

O principal gene que quando mutado é responsável pela síndrome de SaethreChotzen é o TWIST1(El Ghouzzi et al. 1997;Howard et al. 1997). Este codifica uma protéina que é um fator de transcrição da família helix-loop-helix. O mecanismo é a haploinsuficiência (revisão em Wilkie, 1997).

A haploinsuficiência se dá pela perda da proteína no caso de mutações que introduzuem um códon de parada (stop codon) ou pela inacapacidade desta de ligar se ligar ao DNA ou a outras proteínas (El Ghouzzi et al 2000 e 2001). 


\subsubsection{Fatores de crescimentos de Fibroblastos e receptores de fatores de crescimento de fibroblasto}

Em mamíferos, os fatores de crescimento de fibroblastos (fgfs) constituem uma grande família com mais de vinte membros que transduzem sinais por meio de uma classe de receptores com domínio tirosina quinase, os FGFRs (Dickson et al., 2000; De Moerloozee al., 2000). A família dos receptores de fatores de crescimento de fibroblastos (FGFRs) é constituída por menos quatro receptores transmembrana tirosina-quinase que apresentam um domínio extracelular composto por um peptídeo sinal, uma caixa acídica (acidic box), três domínios semelhantes às imunoglobulinas (IgI-III); um domínio transmembrana e o domínio intracelular tirosina-quinase (TK1TK2). O FGFR4 não participa no desenvolvimento ósseo (Warren \& Longaker, 2001; Fujisawa et al., 2002; Kan et al.,2002; Ibrahimi et al., 2004).

A ligação do fgf ocorre no segundo e terceiro domínio imunoglobulina e se dá por meio de moléculas de heparan sulfate (HS), uma glicosaminoglicana que está localizada na superfície da célula e na matriz extracelular. Este complexo trimolecular estimula a atividade dos receptores promovendo sua dimerização, transfosforilação dos resíduos tirosina quinase e, ativação de uma cascata de sinais intracelulares que levam a inúmeras respostas celulares como proliferação, migração, diferenciação e apoptose (Boilly et al., 2000; Mcintosh et al., 2000; Berry et al., 2003).

Nos genes FGFR1, FGFR2 e FGFR3 ocorre splicing alternativo dos exons 9 e10 gerando as isoformas "IIIb" (exons 8 ou IIIa e 9 ou IIIb com ausência do exon 10) ou "'IIIc" (exons 8 ou IIIa e 10 ou IIIc com ausência do exon 9). A primeira metade deste domínio é codificada pelo exon 8 ( ou IIIa) que está sempre presente (Figura 1), enquanto a segunda metade é codificada pelo exon 9 (ou IIIb) ou exon 10 (IIIc) (Ricol, et al. 1999; Fujisawa, et al. 2002; Cohen Jr. 2004). Em FGFR2, o splicing alternativo da região codificadora IgIII gera as isoformas IIIb também conhecida como KGFR e a isoforma IIIc, BeK (Chan \& Thorogood, 1998). Estas duas isoformas são idênticas diferindo por apenas 49 aminoácidos (Fujisawa, et al. 2002). O terceiro domínio é uma região de interface com fgfs e as duas isoformas possuem diferentes afinidades por fatores de crescimento de fibroblastos (Fgfs) sendo que na isoforma IIIb ligam-se Fgf 1, 3, 4 e 7, e na isoforma IIIc ligam-se Fgf 1, 2, 4, 5, 6, 9 e 18 (Cohen Jr. 2004). Essas isoformas apresentam diferentes padrões de expressão na embriogênese murina sendo que a isoforma IIIb parece 
desempenhar um papel no desenvolvimento epitelial e a IIIc é preferencialmente expressa na osteogênese (Cohen Jr. 2004).

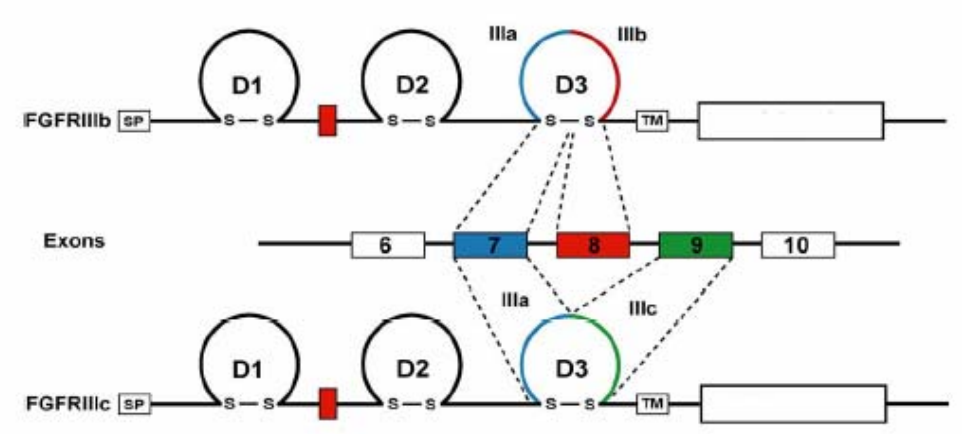

Figura1: Splicing alternativo dos FGFRS $(1,2,3)$ mostrando as duas diferentes isoformas IIIb e IIIc Swarakumar \& Schlessinger, 2005

A importância da sinalização FGF/FGFR no desenvolvimento esquelético foi evidenciada por meio de experimentos em camundongos onde se verificou que mutações nos componentes desta via resultam em anormalidades ósseas, e pela identificação de mutações nos genes FGFRs em diversas formas com craniossinostoses, como já mencionado (Ornitz \& Marie, 2002; Cohen Jr. 1995 ; Cohen Jr. 2004).

A ativação constitutiva do receptor na ausência do ligante (fgf) são os principais efeitos das mutações em FGFRs, particularmente as que causam substituições de aminoácidos. Isto leva a um ganho de função desses genes e é provavelmente o principal mecanismo responsável pela maior parte dos sintomas de craniosinostose sindrômicas. (Baroni et al., 2002; Ornitz \& Marie, 2002; Passos-Bueno et al., 2002). Entretanto, outros mecanismos podem estar envolvidos nesta Síndrome, vindo a explicar os $48 \%$ dos casos descritos anteriormente onde não há mutação nos genes FGFR2, 3 e TWIST1. 
Experimentos utilizando-se inserção retroviral de genes Fgf3 e Fgf4 em camundongos causaram um aumento da expressão do produto deles nesses animais, resultando um fenótipo semelhante à Síndrome de Crouzon (Carlton et al.,1998; Iseki et al.,1999; Ornitz \& Marie, 2002). Também, a implantação de beads contendo Fgf4 em crânios de camundongos neonatais acelerou o fechamento das suturas, em decorrência do aumento da proliferação e diferenciação dos osteoblastos (Kim et al., 1998; Fragale et al., 1999). Assim sendo, é possível que mutações nos genes FGF3 e FGF4 possam causar um fenótipo semelhante à Síndrome de Crouzon ou a outra craniossinostose sindrômica, uma vez que há uma forte sobreposição de sintomas entre as diversas síndromes.

\subsection{2)TWIST 1 e Região 5’a montante do TWIST1}

O principal gene que quando mutado é responsável pela síndrome de SaethreChotzen é o TWIST1, como mencionado anteriormente. Este está mapeado no cromossomo 7 p21 e possui dois exons sendo que o segundo não é traduzido (Wang et al. 1997). O gene TWIST1 foi originalmente identificado como um indutor fundamental da formação do mesoderma em Drosophila, função essa também implicada em vertebrados (Rice et al. 2000; Yang et al., 2004). O gene TWIST1 humano é homólogo ao Twist de Drosophila, apresentando $84 \%$ de conservação da região codificadora entre as duas espécies, sendo que a nível genômico, este gene em humanos é praticamente o mesmo de camundongo (Gachot-Neveu et al., 2002).

Camundongos homozigotos Twist -/- morrem durante a fase inicial do desenvolvimento (Bourgeois et al. 1998). Já animais heterozigotos apresentam comprometimento de neurocrânio e condrocrânio. Podem apresentar comprometimento de dígitos dentre outros sinais, sendo que os animais estudados apresentam uma grande variabilidade fenotípica entre si, semelhante ao observado em pacientes com SaethreChotzen (Bourgeois et al. 1998).

A proteína TWIST contém um domínio de ligação amino-terminal histoneacetyl-transferase (HAT), e um domínio basic-helix-loop-helix (B-HLH) na porção carboxi-terminal, estando estes domínios separados por uma região de ligação (linker region) (Gachot-Neveu et al. 2002). A expressão do TWIST1 tem sido implicada na inibição da diferenciação de múltiplas linhagens celulares incluindo músculos, cartilagem e células 

ósseas e nervosas (Funato et al. 2001). Em camundongo, a proteína Twist é essencial para a migração e localização celular durante a morfogênese de precursores craniais, funcionando dessa forma como um regulador mestre durante a morfogênese embrionária (Yang et al.,2004; Afanador et al. 2005). Está proteína também é importante na regulação do ciclo celular e a alteração dos níveis dessa proteína está envolvida a alguns tumores (Yang et al., 2004).

A elucidação dos mecanismos moleculares que participam na regulação da expressão gênica a nível transcricional e pós-transcricional é um dos maiores desafios da era pós-genômica. Em eucariotos regiões não codificadoras exercem um papel crucial na expressão dos genes (Pesole \& Liuni, 1999). A informação genética para o controle da transcrição é definida por uma série de elementos em cis com o gene de interesse, tais como promotores, enhancers, silencers e locus control regions (LCRs), organizados em uma estrutura modular de arranjos específicos que determinam a especificidade espaço temporal de expressão (Pesole \& Liuni,1999).

Sabe-se que na formação do tecido ósseo, participam mecanismos transcricionais que permitem a indução e a repressão de genes necessários para a diferenciação de células mesenquimais em ósseas (Lian et al., 2003). A regulação do início da expressão de um gene depende geralmente de seqüências de DNA localizadas a 5'do sítio inicial de transcrição (Levine \& Tjian, 2003).

Devido à importância de regiões promotoras na regulação da expressão de genes em eucariotos e com as evidências recentes na literatura do envolvimento destas em muitas patologias genéticas (Chave et al., 2003; Nishioka et al., 2003; Amano et al., 2004; Zhang et al., 2004), pretendemos testar se uma mutação identificada a -18 do primeiro ATG deste gene, em um paciente de nosso laboratório apresentando sinais clínicos compatíveis com o da Síndrome de Saethre-Chotzen, trata-se de uma mutação funcional e patogênica. Esta se encontra dentro do porvável promotor mínimo do gene TWIST1. 



\section{2) OBJETIVOS DO PROJETO}

\section{1) OBJETIVOS GERAIS}

1) Identificar gene (s) responsável (is) por fenótipo de craniossinostosis sindrômicas sem causa conhecida.

2) Caracterizar a funcionalidade de uma região a $5^{\prime}$ 'do primeiro ATG do gene TWIST1.

\section{2) OBJETIVOS ESPECÍFICOS}

1) Caracterizar clinicamente e molecularmente um caso de Pfeiffer III que apresenta eversão sacroccigeal.

2) Verificar se mutações nos genes FGF3 e FGF4 são responsáveis pela ocorrência de craniossinostoses sindrômicas.

3) Verificar se uma mutação localizada a -18 em relação ao primeiro ATG do gene TWIST1 é funcional. 


\section{1) Casuística e Métodos}

\section{1) Seleção de Pacientes e Controles}

Incluímos para o presente estudo 68 amostras de DNA provenientes de pacientes com craniossinostoses sindrômicas. Dentre estes já havíamos verificado que 32 não apresentavam mutações nos genes FGFR1, FGFR2, FGFR3 e TWIST1. O material dos outros 36 pacientes foram testados por mim durante a execução deste trabalho. A listagem completa dos pacientes com o diagnóstico clínico encontra-se no anexo1.

Para os pacientes, responsáveis e indivíduos controles foram explicados os objetivos da pesquisa e requisitada a assinatura do termo de consentimento, conforme resolução 196 do Conselho Nacional de Ética Brasileira. Este projeto consta de autorização do comitê de Ética e pesquisa do Instituto de Biociências (anexo2).

\section{2) Coleta de sangue periférico e extração de DNA}

Foram coletados $10 \mathrm{ml}$ de sangue periférico de cada um dos pacientes participantes do estudo, utilizando-se procedimento padrão.A extração do DNA genômico, a partir de linfócitos, foi realizada com amostras de 5-10 $\mathrm{ml}$ de sangue total coletado em tubos contendo $0,4 \mathrm{ml}$ de EDTA $5 \%$ com anticoagulante. A extração foi realizada de acordo com a metodologia descrita por Miller et al. (1988), que obedece as seguintes etapas:

1. Transferir cada amostra de sangue para um tubo polipropileno (Falcon) e completálo com $50 \mathrm{ml}$ de solução de lise de membrana celular $\left(\mathrm{NH}_{4} \mathrm{Cl} 1550 \mathrm{mM} ; \mathrm{KHCO}_{3} 100\right.$ mM; EDTA 10 mM pH 7,4), sob leve agitação.

2. Manter o tubo no gelo durante 30 minutos.

3. Centrifugar durante 15 minutos a $1800 \mathrm{rpm}$.

4. Desprezar o sobrenadante e lavar o precipitado com $10 \mathrm{ml}$ da solução de lise.

5. Centrifugar novamente por 5 minutos a $2.000 \mathrm{rpm}$.

6. Desprezar o sobrenadante e ressuspender o precipitado em $3 \mathrm{ml}$ de solução de lise dos núcleos (Tris-HCl 100 mM pH 8,0; NaCl 4M; EDTA 20 mM pH 8,2). 
7. Acrescentar $50 \mu \mathrm{l}$ de proteinase $\mathrm{K}$ na concentração de $10 \mathrm{mg} / \mathrm{ml}$ e $300 \mu \mathrm{l}$ de SDS 10\%. Agitar levemente.

8. Incubar os tubos a $37^{\circ} \mathrm{C}$ por um período de 3-24 horas.

9. Após a incubação, adicionar $1 \mathrm{ml}$ de $\mathrm{NaCl} 6 \mathrm{M}$ no tubo e misturar vigorosamente.

10. Centrifugar por 20 minutos a $2.500 \mathrm{rpm}$.

11. Transferir o sobrenadante para outro tubo Falcon limpo e centrifugar por mais 15 minutos a $2500 \mathrm{rpm}$.

12. Transferir o sobrenadante para um tubo de vidro. Precipitar o DNA adicionando duas vezes o volume de etanol absoluto. Inverter o tubo algumas vezes.

13. Recolher o DNA com auxílio de um bastão de vidro e lavá-lo com etanol 70\%.

14. Depositar o DNA em tubo Eppendorf e dissolvê-lo em 200-800 $\mu 1$ de TE $^{-4}$ (Tris-HCl $10 \mathrm{mM}$; EDTA 0,1 mM; pH final de 7,5).

15. Incubar a $65^{\circ} \mathrm{C}$ durante 30 minutos e em seguida armazenar a $4^{\circ} \mathrm{C}$.

A quantificação do DNA foi feita com auxílio de um espectrofotômetro (Ultrospec 3000PRO - Amersham Biosciences) utilizando comprimento de onda igual a $260 \mathrm{~nm}$. Para leitura, foram utilizados $2 \mu \mathrm{l}$ de DNA diluídos em $498 \mu \mathrm{H}_{2} \mathrm{O}$ Milliq. Normalmente o rendimento da técnica acima descrita é de aproximadamente de 300-400 $\mu \mathrm{g}$ de DNA por $10 \mathrm{ml}$ de sangue.

\section{$1.3-P C R$}

O método de PCR (Polymerase Chain Reaction) foi descrito por Saiki et. al. (1985) e é uma técnica que permite a amplificação in vitro de seqüências específicas de DNA, usando a enzima DNA polimerase, os quatro nucleotídeos e um par de primers em fitas de DNA complementares. Os primers são usados para direcionar a síntese de DNA em ciclos repetidos. Em cada ciclo, ambas as fitas servem como moldes para a formação de fitas novas, obtendo-se assim um aumento exponencial do produto. Desta forma, tem sido permitido o estudo de seqüências de interesse pelos métodos convencionais de análise de DNA. As condições gerais de PCR dos DNAs amplificados 
neste trabalho seguem o protocolo padrão abaixo descrito, e detalhes referentes a amplicons específicos se encontram no anexo 3:

50 ng de DNA total

1. $10 \mathrm{mM}$ Tris- $\mathrm{HCl}, 50 \mathrm{mM} \mathrm{KCl}, 1,5 \mathrm{mM} \mathrm{MgCl}_{2}, \mathrm{pH} 9,0$ à temperatura ambiente (em 10X PCR Buffer da empresa Amersham Biosciences)

2. $200 \mu \mathrm{M}$ de cada um dos 4 dNTPs (ATP, CTP, GTP e TTP)

3. $0,50 \mu \mathrm{M}$ de cada primer(foward e reverse)

4. 0,5 unidades da enzima Taq DNA polimerase (Amersham Biosciences)

5. Completar com $\mathrm{H}_{2} \mathrm{O}$ para um volume final

O sucesso da amplificação foi verificado por meio de eletroforese em gel de agarose $1,5 \%$ a $120 \mathrm{~V}$ por uma hora e meia . Aproximadamente $5 \mu \mathrm{l}$ de cada amostra de produto de PCR a ser analisada foi misturado a $1 \mu 1$ de tampão de corrida (sucrose 40\%; bromofenol bleu 0,25\%) e aplicados no gel juntamente com um produto de DNA de tamanho conhecido. Após a corrida, o gel foi corado com brometo de etídeo $(0,5 \mu \mathrm{g} / \mathrm{ml})$ e visualizado em um transiluminador de luz ultra-violeta, a fim de confirmarmos a presença de uma única banda do tamanho esperado.

Os termocicladores utilizados foram da Perkin Elmer e PTC-150 MJ Research.Para amplificação dos exons 7 do gene FGFR1, exons 8 (IIIa) e 10 (IIIc) do FGFR2, exon 7 do FGFR3 seguimos a metodologia de Kan et al. (2002). Padronizamos as condições da PCR para os genes TWIST 1, FGF3 e FGF4 sendo que as condições ótimas de annealing e os primers de cada gene estão descritos na Tabela 3.

Tabela 3 - Primers relacionados aos genes TWIST1,FGF3 e FGF4 e condições ideais de annealing.

\begin{tabular}{l|l|l|c|c}
\hline & \multicolumn{1}{|c|}{ Forward Primer $\left(5^{\prime} \rightarrow 3^{\prime}\right)$} & \multicolumn{1}{c|}{ Reverse Primer $\left(5^{\prime} \rightarrow 3^{\prime}\right)$} & $\begin{array}{c}\text { Annealing } \\
\left({ }^{\circ} \mathrm{C}\right)\end{array}$ & $\begin{array}{c}\text { Fragmentos } \\
(\mathrm{pb})\end{array}$ \\
$\begin{array}{l}\text { Twist } \\
\text { fragmento 1 }\end{array}$ & gtccgtcctcctgctctctc & Cgtctgcagctcctcgtaag & 62 & 460 \\
$\begin{array}{l}\text { Twist } \\
\text { fragmento2 }\end{array}$ & caagaagtctgcgggctgt & agtgaggtgggaaggctgag & 62 & 554 \\
FGF3 exon1 & gaagccggagtcagcatctc & Ctcttctcceggacgtgta & 59 & 576 \\
FGF3 exon2 & tctctacctcctgtccggtgac & ccttggcaaagattctactgcccaca & 59 & 329 \\
FGF3 exon & gtgtgactggctgagagtgcgc & cagggaggacttctgtctgc & 62 & 349 \\
\hline
\end{tabular}




\begin{tabular}{l|l|l|c|c}
\hline 3A & & & \\
FGF3 exon & accggacggtgtctagtacg & gctcaaggaggagagtcagag & 59 & 400 \\
3B & cctcagagtcccagctccag & gagtgtgactgagcgggttg & 60 & 636 \\
FGF4 exon1 & atgtccgctgttccaacgta & 59 & 256 \\
FGF4 exon2 & cccaacccacccagaaatagggt & gtcttcatccgaagaaagtgc & 59 & 358
\end{tabular}


Esse método foi recentemente desenvolvido (Oefner and Underhill, 1995, 1998, 1999; Underhill et al.,1997) e é normalmente referido como desnaturação em cromatografia líquida de alta performance (ou dHPLC). Esta metodologia, que baseia-se na detecção de mutações por meio de análise de heteroduplex de cromatografia modulado por temperatura quando há uma mutação em um dos alelos (Kuklin et al., 1997), é comercializada pela Transgenomic Inc. Para a formação do heteroduplex, o produto de $\mathrm{PCR}$ é aquecido a $95^{\circ} \mathrm{C}$ por 4 minutos e então a temperatura é diminuída $0.3^{\circ} \mathrm{C}$ a cada 10 segundos de forma que no final de 40 minutos a temperatura seja de $25^{\circ} \mathrm{C}$. Atingido este estágio, o programa é finalizado resfriando-se os produtos de PCR à $4^{\circ} \mathrm{C}$.

A triagem de mutações por meio da técnica de dHPLC baseia-se na retenção diferencial de moléculas de heteroduplex de DNA em relação à moléculas de homoduplex em um cartucho de retenção de ácido nucleico sob condições de desnaturação parcial do DNA. Os fragmentos de PCR de heteroduplex contêm uma quantidade maior de regiões não pareadas em comparação aos fragmentos de PCR de homoduplex, sendo assim retidos por menos tempo do que seus análogos homoduplex no cartucho da fase estacionária (Xiao e Oefner, 2001). Inicialmente, o DNA é carreado juntamente com uma solução constante de triethylammonio acetato (TEAA $100 \mathrm{mM}$ ) até o cartucho (DNASep ${ }^{R}$, Transgenomic) de retenção do DNA, fase estacionária. Durante a corrida, quantidades gradativamente crescentes de acetonitrila são adicionada à fase móvel. Esta substância é o solvente orgânico responsável pela liberação do complexo DNAds-TEAA do cartucho. Os fragmentos de DNA liberados são detectadas por um feixe de luz ultra-violeta. Estes sinais são convertidos em valores digitais, apresentados como cromatogramas, nos quais os picos corresponderiam aos fragmentos de DNA.

Utilizamos o programa Wavemaker, que calcula e sugere temperatura de temperaturas parciais ideais para a detecção de mutações ao longo da seqüência de DNA estudada, assim como as porcentagens gradativas de solvente orgânico necessárias para cada seqüência de DNA (protocolo da Transgenomic Inc.).

Durante a padronização de cada produto de PCR, é necessário, fazer um teste de 
qualidade das condições de PCR. Nesta fase, o produto de PCR é aplicado sob condições não desnaturantes no dHPLC. O produto ideal é aquele no qual se verifica apenas um pico no cromatograma (indicando que existem apenas produtos de um mesmo tamanho). Na etapa de testes, devem-se usar amostras controles, pois pacientes portadores de deleção ou duplicação em heterozigose, vão gerar dois picos com base no tamanho diferencial de ambos os alelos (protocolo da Transgenomic Inc.).

Em seguida, as condições teóricas calculadas pelo programa Wavemaker devem ser validadas com testes práticos, de preferência usando-se amostras de controles normais e, quando possível, amostras de pacientes com mutações conhecidas. Nesta fase, após a amplificação do DNA, uma reação adicional para geração de heteroduplex é necessária $\left(95^{\circ} \mathrm{C}\right.$ a 4 minutos, seguidos por redução lenta e gradativa da temperatura de $95^{\circ} \mathrm{C}$ à $25^{\circ} \mathrm{C}$, por aproximadamente 45 minutos).

Uma vez padronizada, a utilização rotineira deste aparelho requer do usuário o cadastro das amostras numa planilha de trabalho do aparelho, e a realização da reação de geração de heteroduplex após a amplificação do DNA (protocolo da Transgenomic Inc.).

Os genes FGFR1,FGFR2 (fragmentos IIIA e IIIC),FGFR, FGF3 e FGF4 foram analisados por meio do método de dHPLC. A relação de temperaturas no dHPLC para análise dos exons desses genes são:

FGFR $1-60^{\circ} \mathrm{C}$

FGFR2IIIA - $61^{\circ} \mathrm{C}$ e $63^{\circ} \mathrm{C}$

FGFR2IIIC- $58^{\circ} \mathrm{C}$

FGFR3- $65^{\circ} \mathrm{C}, 65,5^{\circ} \mathrm{C}$

FGF3 exon1- $62{ }^{\circ} \mathrm{C}, 63,5^{\circ} \mathrm{C}, 65^{\circ} \mathrm{C}$

FGF3 exon2- $61^{\circ} \mathrm{C} ; 63^{\circ} \mathrm{C} ; 65^{\circ} \mathrm{C}$

FGF3 exon3A- $64^{\circ} \mathrm{C} ; 65,5^{\circ} \mathrm{C}$

FGF3 exon3B-65, ${ }^{\circ} \mathrm{C} ; 65,5^{\circ} \mathrm{C}$

FGF4 exon $1-67,5^{\circ} \mathrm{C} ; 68,5^{\circ} \mathrm{C}$;

FGF4 exon2- $63,5^{\circ} \mathrm{C}, 66^{\circ} \mathrm{C}$

FGF4 exon3- $62^{\circ} \mathrm{C} ; 63^{\circ} \mathrm{C}$ 


\section{5 - SEQÜENCIAMENTO AUTOMÁTICO}

Para o seqüenciamento, o produto de PCR foi quantificado por meio de eletroforese em gel de agarose 1,5\% e TBE $1 \mathrm{X}$ utilizando como padrão, uma amostra de concentração conhecida (Low DNA Mass ${ }^{T M}$ Ladder da Invitrogen, ou um outro produto de PCR conhecido). Aproximadamente $40 \mathrm{ng}$ do produto da PCR eram purificados por meio de adição de 10 unidades da enzima Exonuclease I (USB) e de 5 unidades da enzima Shrimp Alkaline Phosphatase (Amersham Biosciences), seguida de incubação a $37^{\circ} \mathrm{C}$ por 30 minutos e inativação da enzima a $80^{\circ} \mathrm{C}$ por 15 minutos.

O produto purificado foi aliquotado em 2 novos tubos de PCR, aos quais foram posteriormente adicionados $4 \mu \mathrm{l}$ de Premix (Amersham Biosciences). Em um dos tubos, adicionavam-se $1 \mu \mathrm{l}(5 \mu \mathrm{M})$ do primer Forward e no outro $1 \mu \mathrm{l}(5 \mu \mathrm{M})$ do primer Reverse, previamente usados na respectiva reação de PCR. O volume final de $10 \mu 1$ era completado com $\mathrm{H}_{2} \mathrm{O}$. A reação de seqüenciamento foi realizada nas seguintes condições: 24 ciclos de desnaturação à $95^{\circ} \mathrm{C}$ por 10 segundos, annealing à $50^{\circ} \mathrm{C}$ por 10 segundos e extensão à $60^{\circ} \mathrm{C}$ por 1 minuto.

O produto da reação de seqüência foi então precipitado de acordo com as seguintes etapas:

1. Acrescentar $1 \mu 1$ de acetato e $27,5 \mu 1$ de etanol absoluto;

2. Centrifugar a $12.000 \mathrm{rpm}$ por 15 minutos;

3. Retirar o sobrenadante, acrescentar $150 \mu \mathrm{l}$ de etanol 70\%;

4. Centrifugar a $12 \mathrm{rpm}$ por 10 minutos;

5. Retirar o sobrenadante;

6. Deixe no gelo os tubos com a tampa aberta por 2 minutos para que todo resíduo de etanol evapore;

8. Acrescente $10 \mu \mathrm{l}$ de Loading Solution (Amersham);

9. Passe os tubos por 10 segundos no vórtex.

Usamos o equipamento MegaBACETM 1000 DNA Analysis Systems (Amersham Biosciences). 


\section{6) Triagem de mutação nos genes FGFR1, FGFR2, FGFR3 e TWIST1}

A triagem de mutação foi realizada por meio de amplificação por PCR das regiões de interesse; e análise do produto amplificado por heteroduplex, utilizando-se a técnica dHPLC (High Performance Liquid Cromathographic). As amostras que apresentarem um padrão alterado, quando comparados com controles normais, foram seqüenciadas no equipamento Megabace usando o kit BigDye Terminator Cycle Sequencing (Amersham Biosciences) para caracterização da natureza da alteração seguimos a nomenclatura proposta por Dunnen \& Antonarakis (2001) para descrever as mutações encontradas.Os amplicons referentes ao gene TWIST1 foram diretamente sequenciados. 


\section{1 Análise da variação na funcionalidade do promotor em relação à mutação encontrada}

Foi realizada também uma construção portando a mutação $-18 \mathrm{~A}>\mathrm{C}$ do gene TWIST1 que será posteriormente utilizada no ensaio da luciferase. Pretendemos avaliar se a seqüência contendo a mutação interfere nos níveis de expressão do gene.

Para isso analisamos a região a montante do exon 1 do gene TWIST1 com o software de predição de elementos transcricionais TESS disponibilizado na internet, na busca de homologia com fatores de transcrição já descritos na literatura (Schug e Overton, 1997).

Realizamos a técnica de Eletrophoretic Mobility Shift Assay (EMSA) com o objetivo de verificar se um dos fatores de transcrição preditos in silico interage com a região onde foi encontrada a mutação. Para essa técnica oligonucleotideos representando seqüências de elementos transcricionais identificados in silico são sintetizados. A esses oligos marcados com $\mathrm{P}^{32}$ é adicionado extrato nuclear com ou sem anticorpo específico para o fator de transcrição em questão. As amostras são aplicadas em um gel de acrilamida $6 \%$ e variações entre o padrão de bandas da amostra com e sem anticorpo indicam se o fator em questão se liga ao oligo, e, portanto a região estudada.

Para a análise da funcionalidade dos elementos transcricionais identificados, utilizamos também a metodologia de ensaio de luciferase descrita em Brophy et al (2001) com vetores pGL-3 da Promega, os quais contém o gene repórter da firefly luciferase. Duas regiões de 400pb a 5' do exon 1 do gene TWIST1 de um indivíduo controle e do paciente portando a mutação, foram amplificadas por polymerase chain reaction (PCR) e clonadas no vetor de expressão pGL3-Basic, utilizando enzimas de restrição adequadas. As construções foram seqüenciadas, para verificar se os clones estavam de acordo com o esperado.

Esses fragmentos foram clonados no vetor pGL3-Basic e isso permitirá uma análise independente da atividade regulatória desses grupos de elementos de transcrição. O vetor de expressão contendo o gene "repórter" e os fragmentos promotores foram transfectados em células 293 (célula de rin embrionário), onde medimos o nível de expressão da proteína "repórter", avaliando a funcionalidade do fragmento em questão. 
Um grupo de células foi transfectado com o vetor pGL3-Basic vazio, que foi o controle negativo, e outro com o vetor pGL3-SV40, que contém o promotor do simian virus 40 antes do gene repórter, sendo este o controle positivo. Os dados foram normalizados 
através da cotransfecção de todos os grupos de células com vetor controle pRLTK (Promega), contendo o promotor da timidina kinase do vírus herpes simplex ligado a um gene repórter da renilla luciferase. O nível de expressão da firefly luciferase será então determinado através da comparação entre o valor gerado pelo vetor "repórter" e pelo vetor normalizador. 


\section{CAPÍTULO III}

“Nova evidência de que mutações no gene FGFR2 causam craniossinostose sindrômica com eversão sacroccigeal”

Este capítulo corresponde ao objetivo 2, e constitui um artigo que foi recentemente aceito para publicação na revista Birth Defects....

Further evidence of association between mutations in FGFR2 and syndromic craniosynostosis with sacrococcygeal eversion.

Submitted to Birth Defects Research on May $29^{\text {th }} 2006$

Nélio A.J. Oliveira ${ }^{\mathrm{a}}$, Luís G. Alonso ${ }^{\mathrm{b}}$, Roberto D. Fanganiello ${ }^{\mathrm{a}}$, Maria Rita PassosBueno $^{\mathrm{a}}$

${ }^{a}$ Centro de Estudos do Genoma Humano, Departamento de Genética e Biologia Evolutiva, Instituto de Biociências, Universidade de São Paulo, São Paulo, Brazil

${ }^{\mathrm{b}}$ Departamento de Morfologia, Escola Paulista de Medicina, Universidade Federal de São Paulo-Escola Paulista de Medicina, Brazil 
Address for correspondence: Maria Rita Passos-Bueno, Rua do Matão, 277,

Departamento de Genética e Biologia Evolutiva, Instituto de Biociências, Universidade de São Paulo, São Paulo, Brazil, CEP05508-900, Phone: 55-11-3091-9910; Fax: 55-113091-7419; e-mail: passos@ib.usp.br

BACKGROUND: Pfeiffer syndrome (OMIM \#101600) is an autosomal dominant disorder 
characterized by craniosynostosis, midface hypoplasia, broad thumbs, brachydactyly, broad great toes and variable syndactyly.

CASE: We report a case of Pfeiffer syndrome (Type 3) with tracheal and visceral involvement and sacrococcygeal eversion. The patient shows facial dysmorphism with macrocephaly, dolicocephaly and trigonocephaly and an asymmetric skull, bilateral and severe exophthalmia with shallow orbits and ocular hypertelorism, downslanting palpebral fissures, constant strabismus, short anterior cranial base and midface hypoplasia.

MOLECULAR ANALYSIS AND CONCLUSIONS: Molecular analysis of the FGFR2 gene in this patient revealed a point mutation (c.890G>C NM_000141). This mutation leads to the substitution of the residue tryptophan at position 290 to cysteine in the protein (p.Try290Cys). These data reinforce the hypothesis that the p.Trp290Cys mutation is more often associated with a severe and poor prognosis of Pfeiffer syndrome. Furthermore they suggest that the presence of sacrococcygeal defects is not associated with any specific FGFR2 mutation.

Key Words: FGFR2, Pfeiffer type 3, sacrococcygeal eversion, Try290Cys 


\section{INTRODUCTION}

Pfeiffer syndrome (PS) (OMIM \#101600) is an autosomal dominant disorder characterized by craniosynostosis, midface hypoplasia, broad thumbs, brachydactyly, broad great toes, and variable cutaneous syndactyly (Tartaglia et al., 1997, Kress et al., 2000, Teebi et al. 2002, Cohen Jr., 2004). The premature fusion of one or more cranial sutures leads to an abnormal skull shape (Tartaglia et al., 1997). There is considerable clinical heterogeneity and three subtypes of Pfeiffer syndrome, with clinical overlap and with different prognostic trends (Cohen Jr., 1993;Cohen Jr., 2004). Classic Pfeiffer syndrome or Pfeiffer syndrome (PS) type 1, the most common of them, usually does not affect intelligence or lifespan. Pfeiffer syndrome type 2 is characterized by the presence of cloverleaf skull, severe ocular proptosis, often severe central nervous system involvement, elbow ankylosis, broad thumbs and great toes (Cohen Jr., 1993). Finally, Pfeiffer syndrome type 3 is similar to type 2 but lacks the cloverleaf skull; severe ocular proptosis, shallow orbits and marked shortness of the anterior cranial base are typical in this subgroup (Cohen Jr., 1993; Cohen Jr. and MacLean 2000). Various gastrointestinal (pyloric stenosis, hypoplastic gallbladder, imperforate anus, intestinal malrotation) and genitourinary (urogenital septal defect,, hydropnephrosis, etc) have been found in association with both PS type 2 or 3 (Cohen Jr. and MacLean, 2000). Patients with PS types 2 and 3 have a very poor prognosis and up to date only sporadic cases have been reported.

Pfeiffer type 1 is genetically heterogeneous. Most cases are caused by several different mutations in exons 8 or 10 of the fibroblast growth factor receptor 2 (FGFR2) and a common mutation, $\mathrm{P} 252 \mathrm{R}$, at the gene encoding the fibroblast growth factor receptor 1(FGFR1), is found in a few cases of PS type 1 (Tartaglia et al. 1997, PassosBueno et al. 1999, Kan et al. 2002, Wilkie 2005). There have been very few reports on 
molecular characterization of PS cases types 2 and 3 , possibly due to the rarity of the cases, and it is still not known if these severe phenotypes are caused by common mutations or if there is genetic heterogeneity. In this report we describe one additional patient with Pfeiffer type 3 and a mutation in the FGFR2 gene.

\section{CASE REPORT AND MOLECULAR STUDIES}

We present a female proband which was born at 37 weeks of gestation to healthy non consanguineous Brazilian parents. Her mother was hypertensive and fetal intrauterine growth retardation was evidenced in the third trimester of pregnancy. Her birth weight was $2,745 \mathrm{~g}$ (between the $25^{\text {th }}$ and $50^{\text {th }}$ centile), length was $41 \mathrm{~cm}\left(<5^{\text {th }}\right.$ centile), and cranial circumference (OFC) was $35 \mathrm{~cm}\left(>90^{\text {th }}\right.$ centile). One-minute and 5-minutes Apgar scores were 8 and 9, respectively.

At clinical evaluation ( 3 months) she weighed $4,100 \mathrm{~g}$ (between the $3^{\text {rd }}$ and $10^{\text {th }}$ centile), had a length of $43 \mathrm{~cm}\left(<3^{\text {rd }}\right.$ centile $)$, and an OFC of $41 \mathrm{~cm}\left(>95^{\text {th }}\right.$ centile). Facial dysmorphism included macrocephaly with dolicocephaly and trigonocephaly showing an asymmetric skull, bilateral and severe exophtalmia with shallow orbits and ocular hypertelorism, downslanting palpebral fissures, constant strabismus, short anterior cranial base and midface hypoplasia. The mandibular hypoplasia was associated with a narrow palate. The child has striking protrusion of the tongue, but of normal size. This appearance seems to be related to mandibular hypoplasia. (Fig. 1A).

She also showed low-set ears, short humerus, limited knee and elbow extensions, single finger crease in the fifth finger of both hands, single finger crease in the second finger of the left hand, broad thumbs deviated radially, broad great toes in a bilateral metatarsus varus, kyphoscoliosis, sacrococcygeal eversion (Fig. 1B) accompanied by a deep sacral dimple, and a malposed and anteriorly placed anus. A 
severe axial hypotonia and retarded psychomotor development were also detected. At 3 months she was submitted to tracheotomy given a persistent upper airway obstruction. A percutaneous endoscopic gastrostomy was also performed. Upper limbs X-ray showed bilateral proximal radioulnar synostosis (Fig.1C). Cerebral magnetic resonance imaging revealed ventriculomegaly accompanied by hydrocephalus, hypoplastic corpus callosum and gyral abnormalities (Fig.1D). Abdominal ultrasound scan and echocardiography were normal. Also, routine biochemical investigations and 400 banding karyotype were normal. The external phenotype was consistent with the diagnosis of Pfeiffer syndrome.

The DNA of peripheral blood lymphocytes was extracted using the Miller et al. (1988) protocol. Exons 8 and 10 of the FGFR2 were amplified as reported by Kan et al (2002). The PCR product of exon 8 showed abnormal peak in High Performance Liquid Cromathographic/ WAVE Transgenomic (DHPLC). Sequence analysis in both directions of the amplified exon 8 revealed the $\mathrm{G}$ to $\mathrm{C}$ mutation at position c. 890 (c.890G $>$ C) (Fig. 2). This nucleotide change leads to the substitution of the residue tryptophan at position 290 for cysteine (p.Trp290Cys).

\section{Discussion}

The clinical features and prognosis of the patient described here are very severe. Considering that the patient does not have cloverleaf skull, we suggest that the phenotype should be classified as Pfeiffer type 3. The propositus presents some particular rare clinical features, such as kyphoscoliosis, malposed and anteriorly placed anus, that have also been described in association with other Pfeiffer type 2 and 3 patients (Cohen Jr. and MacLean, 2000). On the other hand, she presents hypoplasia of the corpus callosum, a clinical alteration that has been mostly associated with Apert phenotype (Tokumaru et al., 1996; Cohen Jr. and MacLean, 2000; Gorlin et al.,2001). In 
addition to these rare abnormalities, the patient has sacrococcygeal eversion accompanied by a deep sacral dimple, corresponding to the seventh case where an association between craniosynostosis and sacrococcygeal eversion exists.

FGF signaling plays a key role in modeling the complex branched structure of the tracheal system of the Drosophila and rat (Sutherland et al. 1996, Sato and Kornberg, 2002, Spilde et al. 2003). Mouse Fgfr2(IIIb) ${ }^{-/-}$embryos fail to form the tracheal bifurcation and show defects in lung development (De Moerlooze L. et al. 2000). In addition, abnormal trachea development or alterations is not rare among FGFR2 mutated patients (Cohen Jr. and MacLean, 2000, Scheid et al. 2002, Gonzales et al. 2005, Lapunzina et al. 2005). These together with the data of the present report further strengthen the role of FGF/FGFR signaling in formation of tracheal system in humans. Genotype-phenotype correlations of patients with FGFR2 mutations have showed that suture and limb development share common molecular pathways. If we take into account that all syndromic craniosynostotic cases with sacroccygeal eversion also present tracheal alterations (Lapunzina et al. 2005, Gonzales et al. 2005, Lajeunie et al. 2006)., we can speculate that an altered common signaling pathway is involved in these two defects

The patient reported here harbors the mutation p.Trp290Cys in the FGFR2, which is a tyrosinase-kinase receptor. The extracellular ligand-binding portion of FGFRs consists of three immunoglobulin-like domains (D1 to D3). D2, D3, and the interconnecting linker bear the determinants for ligand binding and specificity. D1 has been shown to play an autoinhibitory role in FGFR signaling (Pellegrini et al. 2000). Alternative splicing of exons 9 (exon IIIb) or 10 (IIIc) in FGFR2, which codes part of the D3 domain, results respectively in the mesenchymal and epithelial isoforms, with unique ligand binding specificities and tissue localizations. In general, the epithelial 
isoform binds to ligands secreted from the adjacent mesenchyme, whereas the mesenchymal isoform preferentially binds to epithelial ligands (Ornitz et al., 1996). Exon 8 (IIIa) is present in both isoforms.

Mutations in exon 8, such as p.Trp290Cys (c.890G $>$ C), thus affect both isoforms. The residue 290 is located in the D3 domain and plays an important role on the IgIII core formation and therefore, in the recognition and specificity of the FGF ligands (Steinberger et al. 1998, Pellegrini et al. 2000, Stauber et al. 2000). The addition of a cysteine in this position can drastically change the structure of the ligand core of both isoforms or create new dissulfide bonds. These mechanisms can lead to ligand promiscuity or to a constitutive activation of both isoforms.

The mutation p.Trp290Cys has been described in 7 other cases of Pfeiffer type 2 syndrome (Tartaglia et al. 1997, Schaefer et al. 1998, Ariga et al. 2001, Nazzaro et al., 2004, Lajeunie et al. 2006) and in one Crouzon (Table 1). The description of the present patient reinforces the hypothesis that substitution of the Triptofane residue 290 by cysteine is mainly associated with a severe phenotype. In addition, our data further supports the correlation between the severity of the phenotype and the effect of the amino acid substitution at this codon on the protein structure, since substitutions of the codon 290 by arginine or glycine cause milder phenotypes (Lajeunie et al. 2006.). Although there is a clinical overlap among these patients with the pTrp290Cys (Table 1), only our patient presents the sacrococcygeal eversion. In our patient, there is a primary malformation of the backbone leading to the appearance of an anomalous bending. This pathological bending of the sacrococcygeal segment occurred because of the caudal-cranial eversion of the lower end of the backbone, below the soft tissues.

To date, only 6 patients, all with FGFR2 mutations, seem to have been described with syndromic craniosynostosis and coccygeal defects: the patient here reported with PS type 3 and pTrp290Cys, a Crouzon patient with a 12bp insertion at nucleotide 824 (exon 8) (Lapunzina et 
al., 2005), two PS type 2 patients with mutation Ser351Cys (exon 10) (Gonzalez et al. 2005)

and two other PS tpe 2 patients with mutation Tyr340Cys (exon 10) (Lajeunie et al. 2006). The

different mutations of FGFR2 so far described in syndromic craniosynostotic patients associated

with sacrococcygeal defects suggest that this skeletal defect is not associated with specific

FGFR2 mutations with no evidence of genetic heterogeneity

\begin{abstract}
In conclusion, our data further supports the hypothesis that the p.Trp290Cys mutation is more often associated with a severe
and poor prognosis and suggest that the presence of sacrococcygeal defects is not associated with any specific FGFR2 mutation.

The association between sacococcygeal defects and tracheal abnormalities have to be validated in a larger sample.
\end{abstract}

Table 1- Clinical features of patients with Trp290Cys, Tyr340Cys and Ser351Cys mutation

\begin{tabular}{|c|c|c|c|c|c|c|c|c|c|c|c|}
\hline \multirow[t]{2}{*}{$\begin{array}{l}\text { Clinical features of patients with Pfeiffer } \\
\text { syndrome phenotype and Trp290Cys, } \\
\text { Tyr340Cys and Ser351Cys FGFR2 } \\
\text { mutation }\end{array}$} & \multirow[t]{2}{*}{$\begin{array}{l}\text { Tartaglia et } \\
\text { al } \\
\text { 1997(Trp29 } \\
\text { 0Cys) }\end{array}$} & \multirow[t]{2}{*}{$\begin{array}{c}\text { Schaefe } \\
\text { r et al., } \\
1998 \\
\text { (Trp290 } \\
\text { Cys) }\end{array}$} & \multirow[t]{2}{*}{$\begin{array}{c}\text { Lapunzi } \\
\text { na et al. } \\
2005 \\
\text { (ins } 12 p \\
\text { b exon } \\
8 \text { ) }\end{array}$} & \multicolumn{2}{|l|}{$\begin{array}{c}\text { Gonzale } \\
\text { s et al. } \\
2005 \\
\text { (Ser351 } \\
\text { Cys) }\end{array}$} & \multirow[t]{2}{*}{$\begin{array}{c}\text { Ariga } \\
\text { et al., } \\
2001 \\
\text { (Trp29 } \\
\text { 0Cys) }\end{array}$} & \multicolumn{3}{|c|}{$\begin{array}{c}\text { Lajeunie et } \\
\text { al. } \\
2006 \\
\text { (Tyr340Cys) }\end{array}$} & \multirow[t]{2}{*}{$\begin{array}{l}\text { Prese } \\
\mathrm{nt} \\
\text { repor } \\
\mathrm{t}\end{array}$} & \multirow[t]{2}{*}{ Total } \\
\hline & & & & 1 & 2 & & 1 & 2 & 3 & & \\
\hline
\end{tabular}

\title{
Craniofacial abnormalities
}

- Cloverleaf skull

- Craniosynostosis of at least two sutures

- Downslanting palpebral fissures

- Encephalocele

- Fasciostenosis

- Foramen magnum stenosis

- Hypothalamus agenesis

- $\quad$ Limited eye movement

- Low set ears

- Mandibular hypoplasia (micrognathia)

- Mid-facial hypoplasia

- Ocular proptosis

\section{Central nervous system}

- Arnold-Chiari

- Corpus callosum

- Hydrocephaly

- Gyral abnormalities

- Mental retardation/developmental delay

\section{Upper limbs}

- Altered thumbs

- Elbow ankylosis

- Syndactily 
Lower limbs

- Altered toes

- Syndactily

Respiratory system

- Choanal atresia

- Tracheal abnormalities

Cardiovascular system

- Atrial septal defect

- Patent ductus arteriosus

- Vascular alterations

Gastrointestinal system

- Glossoptosis

- Intestinal malformations

- Macrostomia

- Malposed and anteriorly anus

\section{Genitourinary system}

- Urogenital septum defect
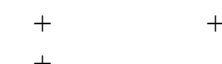

-

$\begin{array}{lllllllllll}- & + & + & + & + & +\end{array}$

Osteomuscular system

- Deep sacral dimple

- Global hypotonia

- Kyphoscoliosis

- Sacrococcygeal eversion

\begin{tabular}{|c|c|c|c|c|c|c|c|c|c|c|}
\hline - & - & - & - & - & + & - & - & - & - & $1 / 7$ \\
\hline+ & - & - & - & - & - & - & - & - & - & $1 / 7$ \\
\hline - & - & - & - & - & - & - & - & - & + & $1 / 7$ \\
\hline - & - & - & - & - & - & - & - & - & + & $1 / 7$ \\
\hline - & + & - & - & - & - & - & - & - & - & $1 / 7$ \\
\hline - & - & - & - & - & - & - & - & - & + & $1 / 7$ \\
\hline- & - & - & - & - & - & - & - & - & + & $1 / 7$ \\
\hline - & - & - & - & - & - & - & - & - & + & $1 / 7$ \\
\hline - & - & + & + & + & - & - & - & - & + & $1 / 7$ \\
\hline
\end{tabular}

Acknowledgements

We would like to thank the family of the patient for the collaboration and Mrs.

Constância Gotto Urbani for the secretarial assistance. This work was sponsored by Fundação de Amparo a Pesquisa do Estado de São Paulo (FAPESP- CEPID) and Conselho Nacional de Pesquisa $(\mathrm{CNPq})$.

\section{References}

Ariga, H., Endo, Y., Ujie, N, Ishil, T., Ishibashi, N., Fujita, T., Suzuki, H. 2001.

TRP290Cys mutation of the FGFR2 gene in a patient with severe Pfeiffer

syndrome type 2. Pediatrics International, 43, 293-295.

Cohen MM Jr Pfeiffer syndrome update, clinical subtypes, and guidelines for differential diagnosis. 1993. Am J Med Genet, 45: 300-307. 
Cohen Jr. MM. Syndromes with craniosynostosis. In: Cohen Jr MM, Maclean RE. (eds) Craniosynostosis: Diagnosis, Evaluation, and Management. New York : Oxford University Press. 2000; 309-441.

Cohen MM Jr. Pfeiffer Syndrome. In: Epstein CJ, Ericson RP, Wynshaw-Boris A (eds). 2004. Inborn Errors of Development - the molecular basis of clinical disorders of morphogenesis. New York: Oxford University Press, 361-365.

De Moerlooze L., Spencer-Dene B., Revest J.M., Hajihosseini M., Rosewell I., Dickson C. 2000. An important role for the IIIb isoform of fibroblast growth factor receptor 2 (FGFR2) in mesenchymal-epithelial signaling during mouse organogenesis. Development, 127: 483-492.

Gonzales M., Hewertz S., Martinovic J., Delahaye S., Bazin A., Loget P., Pasquier L., Merrer M., Bonaventure J. 2005. Vertebral anomalies and cartilaginous tracheal sleeve in three in three patients with Pfeiffer Syndrome carrying the S351C FGFR2 mutation Clinical Genetics 68:179-181.

Gorlin R.J., Cohen Jr.M.M., Hennekam R. C.M. 2001. Syndromes of the head and neck in: Syndromes with craniosynostosis New York: Oxford University Press 654-670

Gripp, K.W., Stolle, C. A., McDonald-McGinn, D.M., Markowitz, R.I., Bartlett, S.P., Katowitz, J.A., Muenke, M.,Zackai, E.H. 1998. Phenotype of the fibroblast growth factor receptor 2 ser351cys mutation: Pfeiffer Syndrome Type III. American Journal of Medical Genetics 78:356-360.

Kan S. H., Elanko N., Johnson D.,Cornejo-Roldan, L., Cook J., Reich E. W, Tomkins S., Verloes A., Twigg S. R. F., Rannan-Eliya S., McDonald-McGinn D. M., Zackai E. H., Wall, S. A., Muenke M., Wilkie A. O. M. 2002. Genomic screening of fibroblast growth-factor receptor 2 reveals a wide spectrum of mutations in patients with syndromic craniosynostosis.American Journal Human Genetics 70, 472-486.

Kress, W., Collmann H., Busse M., Keller-Halliger B., Mueller C.R. 2000. Clustering of FGFR2 gene mutations inpatients with Pfeiffer and Crouzon syndromes (FGFR2associated craniosynostoses). Cytogenetics Cell Genetics 91,134-137. 
Lajeunie E., Huertz S., El Ghouzzi V., Martinovic J., reñiré D., Merrer M., Bonaventure J. 2006. Mutation screening in patients with syndromic craniosynostoses indicates that a limited number of reccurent FGFr2 mutattions accounts for severe forms of Pfeiffer Syndrome European Journal of Human Genetics 1-10.

Lapunzina, P., Fernández A., Sánchez R., Delicado, A., Pipaon, M. S., Pajares, I.L., Molano, J. 2005. A novel insertion in the FGFR2 gene in a patient with Crouzon phenotype and sacroccoccygeal eversion. Birth Defects Research, 73, 61-64.

Miller, S.A., Dykes D.D., Polesky H.F. A simple salting out procedure for extracting DNA from human nucleated cells. 1988. Nucleic Acids Research 16 (3), 1215.

Nazzaro A., Della Monica M, Lonardo F, Di Blasi A, Baffico M, Baldi M, Nazzaro G, De Placido G, Sacarano G. 2004. Prenatal ultrasound diagnosis of a case of Pfeiffer syndrome without cloverleaf skull and review of the literature. Pranatal Diagnostic 11-918-922.

Ornitz D. M., Xu J., Colvin J. S., McEwn DG, MacArthur C.A., Coulieri F., Gao G., Goldfab M. 1996. Receptor specificity of fibroblast growth factor family. The journal of biology chemistry, 271:15292-15297.

Passos-Bueno M.R., Wilcox W.R., Jabs E.W., Sertie A.L, Kitoh H. 1999. Clinical spectrum of fibroblast growth factor receptor mutations. Humam Mutation 14,115125 .

Pellegrini L., Burke D.F., Delft F., Mulloy B., Blundell T. L. 2000. Crystal structure of fibroblast growth factor receptor ectodomain bound to ligand and heparin. Nature, 407: 1029-1035.

Sato M. Kornberg T. B. FGF is an essential mitogen and chemoattractant for the air sacs of the Drosophila tracheal system. 2002. Developmental Cell, 3, 195-207. 
Schaefer F., Anderson C., Can B., Say B. 1998. Novel mutation in the FGFR2 gene at the same codon as the Crouzon Syndrome Mutations in a severe Pfeiffer Syndrome Type 2 case. American journal of Medical genetics 75: 252-255.

Scheid S.C., Spector A. R., Luft J.D. 2002. Tracheal cartilaginous sleeve in Crouzon Syndrome. International Journal of Pediatric Otorhinolaryngology, 65: 147-152.

Spilde T. L., Bhatia A.M., Marosky J.K., Preuett B., Kobayashi H., Hembree M.J., Prasadan K., Daume E., Snyder C.L., Gittes G.K. 2003. Fibroblast growth factor signaling in the developing tracheoesophageal fistula. Journal of pediatric surgery, 38: $474-477$.

Steinberg, D. ,Vriend, G, Mulliken, J.B., Muller, U. 1998. The mutations in FGFR2associated craniosynostoses are clustered in five structural elements of imunoglobulin-like domain III of the receptor. Human genetics 102-145-150.

Stauber D. J., DiGabriele A. D., Hendrickson W.A. 1999. Structural interactions of fibroblast growth factor receptor with its ligands. PNAS, 97: 49-54.

Sutherland D., Samakovlis C., Krasnow M. A. 1996. Branchless encodes a Drosophila FGF homolog that controls tracheal cell migration and the pattern of branching. Cell, 87 1091-1101.

Tartaglia, M., Valeri, S., Velardi, F., Di Rocco, C., Battaglia, P.A. 1997. Trp290Cys mutation in exon IIIa of the fibroblast growth factor receptor 2 (FGFR2) gene is associated with Pfeiffer syndrome. Human Genetics, 99:602-606.

Teebi, A. S., Kennedy, S., Chun, K., Ray, P.N. 2002. Severe and mild phenotypes in Pfeiffer Syndrome with splice acceptor mutations in exon IIIc of FGFR2. American Journal of Medical Genetics, 107: 43-47.

Tokumaru A. Y. , Barkovich A.J., Ciricillo S.F., Edwards M.S.B. 1996. Skull base and calvarial deformities: Association with intracranial changes in craniofacial syndromes. AJNR Am J Neuroradiol, 17: 620-630. 
Urtreger A., Givol D., Yayon A., Yarden Y., Lonai P. 1991. Developmental expresión of two murine fibroblast growth factor receptors, flg and bek. Development 113: $1419-1434$.

Walshe J.,Mason I. 2000. Expression of FGFR1, FGFR2 and FGFR3 during early neural development in the chick embryo. Mechanism of Development, 90: 103-110.

Wang Y., Xiao R., Yang F., Karim B. O., Iacovelli A.J., Cai J., Lerner C.P., Richtsmeier J. T., Leszl J. M., Hill C. A, Yu K., Ornitz D.M., Elisseeff J., Huso D.L., Jabs E. W. 2005. Abnormalities in cartilage and bone development in the Apert syndrome FGFR2 $2^{+/ \mathrm{S} 252 \mathrm{~W}}$ mouse. Development 132, 3537-3548.

Wilkie, A.O.M. 2005. Bad bones, absent smell, selfish testes: The pleiotropic consequences of human FGF receptor mutations. Cytokine\& Growth Factors Reviews, 16: 187-203.

Legend for figures
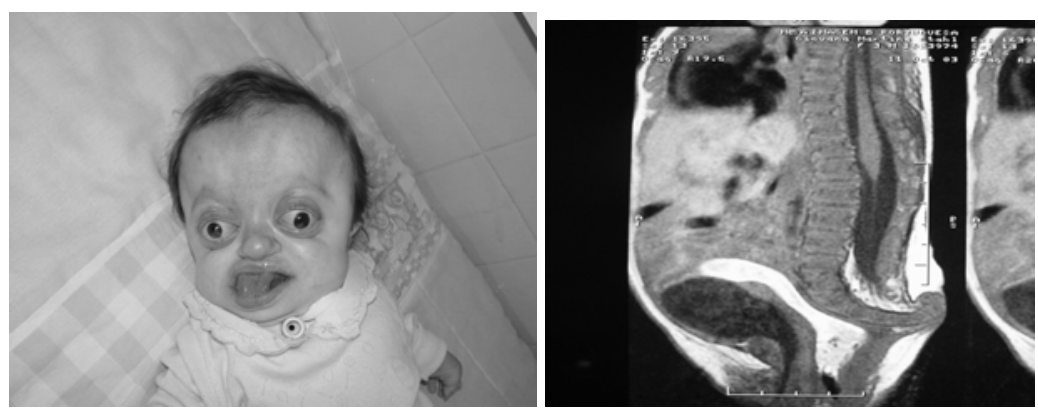

A

B
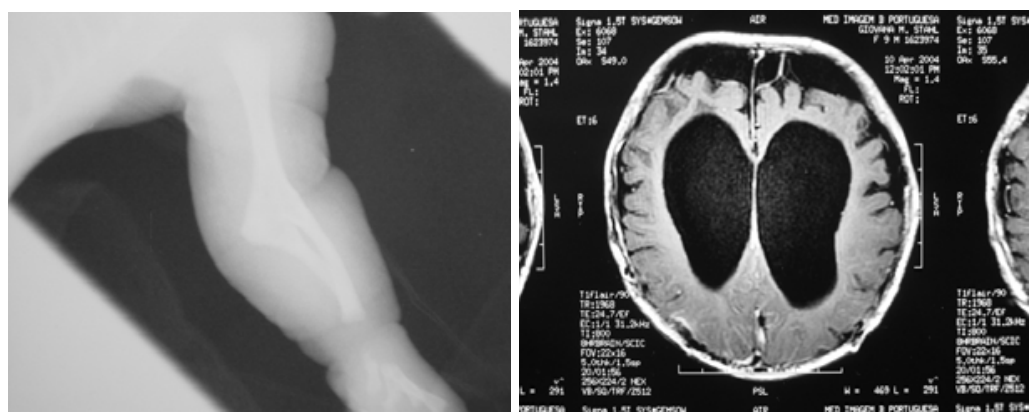

C

D 
Figure 1. Facial and cranial phenotype dysmorphism (A),

sacrococcygeal eversion (B), bilateral proximal radioulnar synostosis (C)

anomalies in the brain (D)

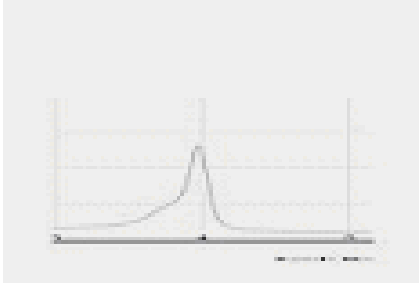

A

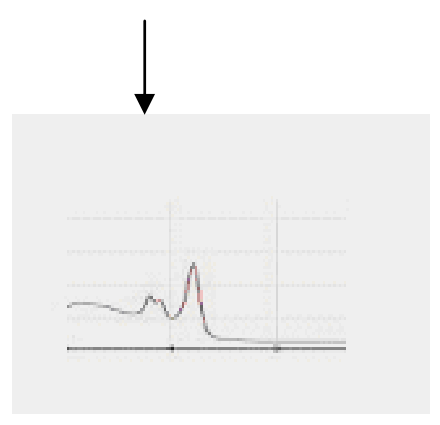

B

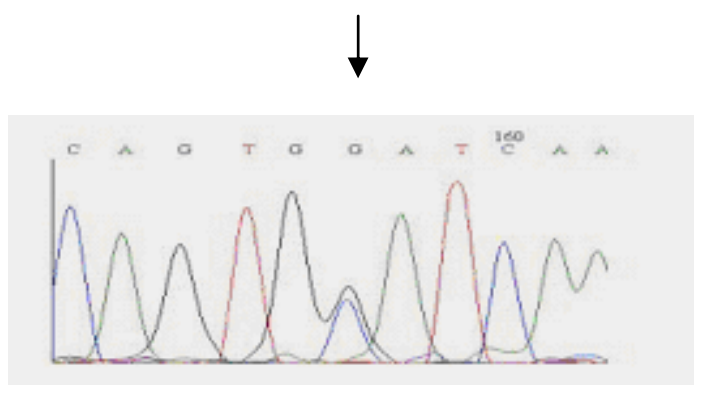

$\mathrm{C}$

Figure 2. Control DHLPC analysis (A), patient DHLPC analysis (B),

(C) sequence analysis showing the $\mathrm{G}$ to $\mathrm{C}$ change 


\title{
CAPÍTULO IV
}

Análise dos genes FGF3 e FGF4 em pacientes com craniossinostose sindrômica

\author{
Nélio A.J. Oliveira, Luis Alonso, Chong AE Kim, Débora Bertola ,Maria \\ Rita Passos-Bueno
}

Resumo: Resumo: As craniossinostoses sindrômicas representam um grupo heterogêneo de desordens, que por definição caracteriza-se pela fusão prematura de uma ou mais suturas cranianas associadas a alguma outra anomalia, como problemas na formação de membros, má formação facial, hipertelorismo, proptose ocular, retardo mental, dentre outros. Alterações nos genes EFBN-1,FGFR1, FGFR2, FGFR3, MSX2 TWIST1 correspondem a aproximadamente $20 \%$ dos casos de craniossinostoses sindrômicas. A identificação de outros genes envolvidos no desenvolvimento das suturas cranianas é imprescindível para melhorar o aconselhamento genético e também, para aumentar nossa compreensão a respeito dos processos que desencadeiam a formação dos elementos que formarão a caixa craniana. Sendo assim, neste trabalho estudamos os genes FGF3 e FGF4 em 47 pacientes com craniossinostoses sindrômicas, que haviam sido excluídos para mutações nos genes já conhecidos como associados a este grupo de doenças. Nossos resultados sugerem que pequenas mutações não são responsáveis pelo quadro clínico das craniossinostoses sindrômicas. 


\section{Introdução}

Craniossinostoses representam um grupo heterogêneo de desordens, que por definição caracteriza-se pela fusão prematura de uma ou mais suturas cranianas. Podem ser classificadas em função do formato que o crânio adquire ou em não-sindrômicas (quando o único problema é o fechamento precoce da sutura craniana) e em sindrômicas (quando outras anomalias estão associadas, como problemas na formação de membros, má formação facial, hipertelorismo, proptose ocular, retardo mental, dentre outros). A incidência é de 1/2500 nascimentos (Kan et al. 2002; Passos-Bueno et al. 1999; Ibrahimi et al. 2003). O padrão de herança para a maioria das craniossinostoses sindrômicas é o autossômico dominante.

Os genes conhecidos envolvidos com craniossinostoses sindrômicas são os receptores de fatores de crescimento de fiboblastos, (FGFR1,FGFR2,FGFR3), os fatores de transcrição MSX2 e TWIST1e o receptor de epinefrina 1(EFBN-1) (PassosBueno et al., 1999;Nacamuli et al., 2002; Morris-Kay \& Wilkie, 2005).Alterações nestes genes correspondem a aproximadamente $20 \%$ dos casos de craniossinostoses sindrômicas (Passos-Bueno et al. 1999, Glaser et al. 2000, Wilkie, 2005).A identificação de outros genes envolvidos no desenvolvimento das suturas cranianas é imprescendível para melhorar o aconselhamento genético e também, para aumentar nossa compreensão a respeito dos processos que desencadeiam a formação dos elementos que formarão a caixa craniana.

Utilizando-se de ensaios retrovirais na região entre os genes Fgf3 e Fgf4 em camundongos, Carlton e colaboradores (1998) observaram um aumento da expressão do produto destes genes nestes animais, o que resultou num fenótipo similar à Sindrome de Crouzon (Carlton et al.1998; Iseki et al.1999; Ornitz \& Marie, 2002). A implantação de beads contendo a proteína fgf4 na caixa craniana de camundongos recém nascidos acelerou o fechamento das suturas, devido ao aumento da proliferação e diferenciação de osteoblastos (Kim et al., 1998;Carlton et al.1998; Iseki et al.1999; Fragale et al., 1999, Ornitz \& Marie, 2002).

Dessa forma, é possível que mutações nos genes FGF3 e FGF4 possam estar relacionadas com craniossinostoses. Uma possível alteração na região codificadora destes genes, poderia estar aumentando a afinidade do ligante ao receptor, ou, está diminunido a dissociação com os ligantes, contribuindo assim para a ativação constitutiva das proteínas 
FGFR1, FGFR2 e ou FGFR3, efeito este similar a muitas mutações estudadas nestes três genes.

Nós estudamos neste trabalho os genes FGF3 e FGF4 em pacientes com craniossinostoses sindrômicas, cujo fenótipo não foi associado à mutação nos genes FGFR1, FGFR2, FGFR3 e TWIST1.

\section{Pacientes e Métodos}

Foram selecionados para o presente estudo 47 pacientes que apresentavam fenótipos compatíveis com o das Síndromes de Crouzon $(n=6)$, Pfeiffer $(n=6)$ e Saethre-Chotzen $(n=3)$, Trigonocefalia sindrômica $(n=9)$, craniosinostoses sindrômicas não classificadas em nenhuma síndrome conhecida $(n=23)$ e que não apresentaram mutação no gene TWIST1 ou nos exons dos genes FGFR1, FGFR2, FGFR3 que podem estar associados a craniossinostose sindrômica. Os pacientes e/ou os responsáveis foram informados sobre o objetivo da pesquisa, sendo que este trabalho consta de aprovação no comitê de ética deste instituto.

O DNA de linfócito de sangue periférico foi extraído usando o protocolo de Miller et al.(1998). Os exons dos genes FGF3 e FGF4 foram amplificados usando os pares de primers descritos na tabela 1. As condições de PCR encontram-se descritas na tabela 2. Os produtos amplificados foram analisados por meio da técnica do heteroduplex que utiliza a tecnologia do aparelho DHPLC (WAVE of Transgenomic). Os produtos que apresentaram alteração no perfil quando comparados com a amostra controle foram seqüenciados usando o sistema dyEnamic ${ }^{\mathrm{TM}}$ dye terminator kit protocol (Amersham Biosciences) que emprega o aparelho sequenciador automático Megabace. 
Tabela 1- Sequência dos primers dos genes FGF3 e FGF4 exons 1, 2, 3A ,3B e; FGF4 exons $1,2 e 3$

\begin{tabular}{l|l|l|l}
\hline Nome & $\begin{array}{l}\text { Tamanho } \\
\text { Amplicon }\end{array}$ & FOWARD 5'-3' & REVERSE 5' $\mathbf{3}^{\prime}$ \\
\hline FGF3 Exon 1 & $576 \mathrm{pb}$ & gaagccggagtcagcatctc & ctcttctcceggacgtgta \\
\hline FGF3 Exon 2 & $329 \mathrm{pb}$ & tctctacctcctgtccggtgac & ccttggcaaagattctactgcccaca \\
\hline FGF3 Exon 3A & $349 \mathrm{pb}$ & gtgtgactggctgagagtgcgc & cagggaggacttctgtctgc \\
\hline FGF3 Exon 3B & $400 \mathrm{pb}$ & accggacggtgtctagtacg & gctcaaggaggagagtcagag \\
\hline FGF4 Exon 1 & $630 \mathrm{pb}$ & cctcagagtcccagctccag & gagtgtgactgagcgggttg \\
\hline FGF4 Exon 2 & $256 \mathrm{pb}$ & cccaacccacccagaaatagggt & atgtccgctgttcccaacgta \\
\hline FGF4 Exon 3 & $358 \mathrm{pb}$ & gtgggacagaagg gggttctgacc & ctcttcatccgaagaaagtgc \\
\hline
\end{tabular}

Tabela 2- Condições de PCR dos genes FGF3 eFGF4

2A- Condições de PCR dos fragmentos dos genes FGF3 exons 2, 3A e 3B ; FGF4 exons 2 e 3

\begin{tabular}{|c|c|}
\hline Reagentes & 1 Reação \\
\hline Buffer 10x Amersham & $2,5 \mu \mathrm{l}$ \\
\hline $\mathrm{dNTP} 2,5 \mathrm{mM}$ & $2,0 \mu \mathrm{l}$ \\
\hline Primer F 20mM & $1,00 \mu 1$ \\
\hline Primer R 20mM & $1,00 \mu \mathrm{l}$ \\
\hline 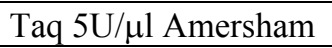 & $0,15 \mu \mathrm{l}$ \\
\hline $\mathrm{H}_{2} \mathrm{O}$ milliQ & $16,85 \mu \mathrm{l}$ \\
\hline Total & $23 \mu \mathrm{l}(+2 \mu \mathrm{l}$ DNA $50 \mathrm{ng} / \mu \mathrm{l})$ \\
\hline
\end{tabular}

2B- PCR Condições de PCR dos fragmentos dos genes FGF3 exon 1 e FGF4 exon 1

\begin{tabular}{|c|c|}
\hline Reagentes & 1 Reação \\
\hline DMSO $10 \%$ & $2,5 \mu \mathrm{l}$ \\
\hline Buffer 10x Amersham & $2,5 \mu \mathrm{l}$ \\
\hline dNTP 2,5mM & $2,0 \mu \mathrm{l}$ \\
\hline Primer F 20mM & $1,00 \mu \mathrm{l}$ \\
\hline Primer R 20mM & $1,00 \mu \mathrm{l}$ \\
\hline Taq 5U/ $\mu 1$ Amersham & $0,15 \mu \mathrm{l}$ \\
\hline $\mathrm{H}_{2} 0$ milliQ & $13,85 \mu \mathrm{l}$ \\
\hline Total & $23 \mu \mathrm{l}(+2 \mu \mathrm{l}$ DNA $50 \mathrm{ng} / \mu \mathrm{l})$ \\
\hline
\end{tabular}




\section{Resultados e Discussão}

A análise das seqüências das amostras dos genes FGF3 e FGF4 que apresentaram alterações no DHPLC revelou a presença de 3 padrões, uma no gene FGF3 e duas outras no gene FGF4. O sequenciamento de produtos de PCR correspondendo a cada um destes padrões revelou que correspondem as seguintes alterações: c.173A>T/FGF3, g.2474C>T /FGF4 e g.4383G>A/FGF4. Estas alterações já foram descritas anteriormente na literatura (Http://www.ncbi.nlm.nih.gov/ entrez /query.fcgi? $\mathrm{CMD}=$ search $\& \mathrm{DB}=\mathrm{snp}$ ) e não há nenhuma evidência sugerindo que sejam funcionais.

Os SNPs c.173A > T/FGF3e g.2474C $>$ T /FGF4 apresentaram uma freqüência de $0.9 \%$, enquanto o SNP g. $4383 \mathrm{G}>\mathrm{A} / \mathrm{FGF} 4$ apresentou uma freqüência de $20 \%$. Este último foi encontrado também em três amostras controles, sendo uma delas identificadas em homozigose,em uma de nossas amostras controles. Há vários outros polimorfismos descritos nos genes FGF3 e FGF4, porém nenhum deles foi encontrado na nossa amostra. Como a freqüências destes polimorfismos não está descrita, é possível, que estes tenham uma freqüência baixa, ou podem ser mais freqüentes em outras populações. O sistema de triagem de mutações que utilizamos, o dHPLC, apesar de não detectar $100 \%$ das alterações, é bastante sensível; contudo, não podemos descartar que estas alterações não foram identificadas em função do método.

Estes resultados, portanto, sugerem que as alterações encontradas nos genes FGF3 e FGF4 não estão associadas ao quadro clínico. Ainda, é importante ressaltar que não identificamos nenhuma mutação rara que pudesse explicar o fenótipo. Todavia, identificamos recentemente em nosso laboratório um paciente com duplicação da região do cromossomo 11, que contem os genes FGF3 e FGF4. Este paciente tem como principal alteração clínica, craniossinostose de todos as suturas. Considerando-se os dados clínicos, as possíveis funções de FGF3 e FGF4, e os dados do camundongo em que há aumento de expressão de Fgf3 e Fgf4 (Carlton et al. 1998), sugerimos que que estes dois genes estão envolvidos com craniossinostose (Jehee, 2005 (tese); Jehee et al., 2006). O efeito funcional de duplicações pode ser comparado ao de mutações de ponto que levam a ganho de função da proteína envolvida. Assim sendo, é possível que duplicações gênicas em vez de mutações pontuais sejam responsáveis por um quadro sindrômico de craniossinostose e isto explicaria os resultados negativos obtidos na 
triagem do pacientes selecionados. Estamos no momento padronizando um método que possibilite a triagem de duplicações dos genes FGF3 e FGF4.

Tabela 3-Polimorfismos identificados neste estudo

\begin{tabular}{l|l|l|l|l|l}
\hline Gene & Posição & Localização & SNP & $\begin{array}{l}\text { Número no } \\
\text { SNPbank NCBI }\end{array}$ & $\begin{array}{l}\text { Número de } \\
\text { pacientes }\end{array}$ \\
\hline FGF3 & c. 173 A $>$ T (Xm 291913) & Região codificadora & A-T & rs12795149 & 1 \\
\hline FGF4 & g. 2474 C $>$ T (Jo2986) & Região codificadora & C-T & rs3808984 & 1 \\
\hline FGF4 & g. 4383 G $>$ A (Jo2986) & Região 3' a jusante & G-A & rs3740639 & 10 \\
\hline
\end{tabular}

\section{Agradecimentos}

Gostaríamos de agradecer os pacientes e seus familiares pela colaboração.Gostaríamos de agradecer a Senhora Constância Gotto Urbani pela assistência secretarial. Este trabalho foi realizado graças ao suporte financeiro da Fundação de Amparo a Pesquisa do Estado de São Paulo (FAPESP) e pelo Conselho Nacional de Pesquisa (CNPq).

\section{Referências}

Carlton, M. B., Colledge W.H., Evans M. Crouzon-like craniofacial dysmorphology in the mouse is caused by an insertional mutation at the Fgf3/Fgf4 locus. Developmental Dynamics, 212,242-9, 1998.

Fragale, A., Tartaglia M., Bernardini S., Di Stasi A.M. M., Di Rocco C., Velardi F., Teti A., Battaglia P.A., Migliaccio S. Decreased proliferation and altered differentiation in osteoblasts from genetically and clinically distinct craniosynostotic disorders. American Journal of Pathology.154 (5) 1465-1477,1999.

Glaser, R. L., Jiang W., Boyadjiev S.A., Tran A.K., Zachary A.A., Van Maldergem L., Johnson D., Walsh S., Oldrige M., Wall S.A., Wilkie A.O.M., Jabs E. W. Paternal origin of FGFR2 mutations in sporadic cases of Crouzon syndrome and Pfeiffer syndrome. American Journal Human Genetics 66, 768-777, 2000.

Gripp, K.W., Stolle, C. A., McDonald-McGinn, D.M., Markowitz, R.I., Bartlett, S.P., Katowitz, J.A., Muenke, M.,Zackai, E.H. Phenotype of the fibroblast growth factor receptor 2 ser351cys mutation: Pfeiffer Syndrome Type III. American Journal of Medical Genetics 78:356-360, 1998.

Ibrahimi, O. A., Zhang F., Eliseenkova A.V., Linhardt R. J., Mohammadi M. Proline to arginine mutations in FGF receptors 1 and 3 result in Pfeiffer and Muenke craniosynostosis syndromes through enhancement of FGF binding affinity. Human Molecular Genetics 13(1): 6978, 2004. 
Iseki, S., Wilkie, A.O.M., Morris-Kay G.M. Fgfr1 and Fgfr2 have distinct differentiation- and proliferation-related roles in the developing mouse skull vault. Development 126 5611-5620, 1999.

Kan S. H., Elanko N., Johnson D.,Cornejo-Roldan, L., Cook J., Reich E. W, Tomkins S., Verloes A., Twigg S. R. F., Rannan-Eliya S., McDonald-McGinn D. M., Zackai E. H., Wall, S. A., Muenke M., Wilkie A. O. M. Genomic screening of fibroblast growth-factor receptor 2 reveals a wide spectrum of mutations in patients with syndromic craniosynostosis.American Journal Human Genetics 70, 472-486, 2002.

Kim, H. J., Rice D.P., Kettunen P.J., Thesleff I. FGF-, BMP- and Shh-mediated signalling pathways in the regulation of cranial suture morphogenesis and calvarial bone development. Development 125(7), 1241-1251, 1998.

Kress, W., Collmann H., Busse M., Keller-Halliger B., Mueller C.R. Clustering of FGFR2 gene mutations inpatients with Pfeiffer and Crouzon syndromes (FGFR2-associated craniosynostoses). Cytogenetics Cell Genetics 91,134-137, 2000.

Miller, S.A., Dykes D.D., Polesky H.F. A simple salting out procedure for extracting DNA from human nucleated cells. Nucleic Acids Research 16 (3), 1215. 1988.

Morris-Kay GM \& Wilkie A.O.M. Growth of the normal skull vault and its alteration in craniosynostosis: insights from human genetics and experimental studies. Journal Anatomy. 2005 Nov;207(5):637-53, 2005.

Nacamuli, R. P., K. D. Fong, et al. Markers of osteoblast differentiation in fusing and nonfusing cranial sutures. Plast Reconstr Surg, v.112, n.5, Oct, p.1328-35. 2003.

Ornitz, D. M. \& Marie P. J.. FGF signaling pathways in endochondral and intramembranous bone development and human genetic disease. Genes in Development 16 (12), 1446-1465, 2002.

Passos-Bueno M.R., Wilcox W.R., Jabs E.W., Sertie A.L, Kitoh H. Clinical spectrum of fibroblast growth factor receptor mutations. Humam Mutation 14,115-125, 1999.

Tartaglia, M., Valeri, S., Velardi, F., Di Rocco, C., Battaglia, P.A., Trp290Cys mutation in exon IIIa of the fibroblast growth factor receptor 2 (FGFR2) gene is associated with Pfeiffer syndrome. Human Genetics, 99:602-606, 1997.

Teebi, A. S., Kennedy, S., Chun, K., Ray, P.N., Severe and mild phenotypes in Pfeiffer Syndrome with splice acceptor mutations in exon IIIc of FGFR2. American Journal of Medical Genetics, 107: 43-47, 2002.

Wilkie, A.O.M., Bad bones, absent smell, selfish testes: The pleiotropic consequences of human FGF receptor mutations. Cytokine\& Growth Factors Reviews, 16: 187-203, 2005. 
Análise do gene TWIST1 em pacientes com síndrome de Saethre-Chotzen: descrição de três novas mutações.

Nélio A.J. Oliveira, Antero F. Macedo, Lúcia M. Armelin-Correa, Ieda Orioli, Mary C. Sogayar, Maria Rita Passos-Bueno

Resumo: A Síndrome de Saethre-Chotzen é uma doença genética autossômica dominante caracterizada por fusão precoce das suturas coronais, hipertelorismo, proptose ocular, alteração de membros e em alguns casos, um leve retardo mental. Mutações no fator de transcrição TWIST1 foi associada com esta síndrome. Estas mutações levam a perda de função da proteína e as evidências apontam a haploinsuficiência como o mecanismo responsável por esta doença. Apesar do mecanismo molecular ser conhecido, não há ainda uma explicação para entendermos a variabilidade clínica destes pacientes. Neste trabalho realizamos o estudo molecular do gene TWIST1 em 7 pacientes com quadro clínico da Síndrome de Saethre-Chotzen. Encontramos quatro mutações. Dentre estas, 3 são patogênicas e duas estamos descrevendo aqui pela primeira vez . A quarta mutação, também nunca descrita anteriormente, foi encontrada em região regulatória do gene TWIST1 e estudos funcionais foram então conduzidos. 


\section{Introdução}

A Síndrome de Saethre-Chotzen (OMIM \#101400) é uma doença genética autossômica dominante caracterizada por fusão precoce das suturas coronais , hipertelorismo, proptose ocular, alteração de membros e em alguns casos, um leve retardo mental (Bourgeois et al. 1998, Paznekas et al. 1998, Cohen \& MacLean 2004). Esta sindrome caracteriza-se também por ter uma alta penetrância e uma grande variabilidade fenotípica. Alguns pacientes que não apresentam comprometimento de membros eventualmente são diagnosticados como portadores da Síndrome de Crouzon ou algum outro tipo de craniossinostose (Bourgeois et al. 1998; Paznekas et al. 1998).

A incidência desta patologia é de aproximadamente 1 em 25000 a 1 em 50000 nascimentos (Krebs et al. 1997). Mutações que criam código de parada prematuro ou que levam a substituição de aminoácidos (missense) no fator de transcrição TWIST foi associada com esta síndrome (El Ghouzzi et al. 1997, Howard et al. 1997;Yousfi et al., 2002, Kress et al. 2005). Considerando-se o tipo destas mutações e os estudos funcionais já realizados, haploinsuficiência parece ser o mecanismo responsável por esta doença (revisão em Wilkie 1997 ;Yousfi et al. 2002, Demontis et al. 2005). Camundogos homozigotos nocaute para este gene têm morte fetal logo no início do desenvolvimento enquanto os camundongos heterozigotos apresentam fenótipo semelhante aos portadores da Síndrome de Saethre-Chotzen. Este modelo animal confirma o modelo de haploinsuficiência como o responsável pela doença (Bourgeois et al. 1998).

O gene TWIST1 está localizado no cromossomo 7p21 e possui dois exons sendo que, o segundo não é traduzido (Wang et al. 1997, Warren \& Longaker, 2001). A proteína TWIST compreende 202 aminoácidos e pertence à classe basic helix-loop-helix (bHLH) e é expressa no mesoderma pelas células da crista neural durante a embriogênese tanto em invertebrados como em vertebrados (Funato et al. 2001, Funato et al. 2005). Esta proteína regula a diferenciação mesodérmica e a miogênese, sendo que o envolvimento deste gene com craniossinostose sugere que este tem um importante papel na osteogênese craniana (Yousfi et al. 2002).

Há mais de 50 mutações descritas na literatura e a descrição de novas mutações podem contribuir para a identificação de regiões funcionais importantes do gene ou para a uma melhor caracterização do fenótipo. Neste estudo nós investigamos a presença de 
mutações em 7 pacientes com quadro clínico possível de Síndrome de SaethreChotzen.

\section{Pacientes e Métodos}

Selecionamos para o presente estudo 7 pacientes diagnosticados clinicamente como portadores da Síndrome de Saethre-Chotzen. Os objetivos da pesquisa foram informados aos pais e ou responsáveis, e este trabalho consta de aprovação no comitê de ética deste instituto.O DNA de sangue de linfócito periférico dos pacientes e de seus famíliares foi extraído usando o protocolo de Miller et al. (1988).

O exon 1 deste gene foi amplificado seguindo as seguintes condições: 10X PCR Buffer 2,5 $\mathrm{L}$, DNTP's 2,0 $\mu \mathrm{L}$, DMSO 10\% 2,5 $\mu$, primers (forward and reverse), 1,25 $\mu \mathrm{L}$ de cada, 0,2 $\mu \mathrm{L}$ TaqPha ${ }^{\circledR}$ e $\mathrm{H}_{2} 0$ Milli-Q 13,30. O volume final da reação foi de 25 $\mu \mathrm{L}$. Adicionamos $2 \mu \mathrm{L}$ de DNA a $50 \mathrm{ng} / \mu \mathrm{L}$ de cada amostra. Os primers utilizados estão listados na tabela 1. Os produtos sequenciados foram bidirecionalmente sequenciados usando o protocolo dyEnamic ${ }^{\mathrm{TM}}$ dye terminator kit (Amersham Biosciences) e o sequenciador automático Megabace. Para cada mutação nova, testasmos 70 amostras de DNA de controles. O método usado para a triagem de mutações nos controles foi o de heteroduplex com o sistema High Performance Liquid Cromathographic/ WAVE Transgenomic (DHPLC).

Tabela 1: Primers dos fragmentos do gene TWIST1

\begin{tabular}{lllll}
\hline Nome & $\begin{array}{l}\text { Amplicon } \\
\text { Size }\end{array}$ & FOWARD 5'-3' & REVERSE $5^{\prime} \mathbf{3}^{\prime}$ & Aneling temperature \\
\hline Twist fragment 1 & $460 \mathrm{pb}$ & Gtccgtcctcctgctctctc & cgtctgcagctcctcgtaag & $62^{\circ} \mathrm{C}$ \\
\hline Twist fragment2 & $554 \mathrm{pb}$ & Caagaagtctgcgggctgt & agtgaggtgggaaggetgag & $62^{\circ} \mathrm{C}$ \\
\hline
\end{tabular}

O programa TESS (transcription factors sites search) disponibilizado gratuitamente na internet (http://www.cbil.upenn.edu/cgi-bin/tess/tess) foi utilizado para caracterizamos in silico a região $5^{\prime}$ reguladora do gene TWIST 1 bem como avaliarmos um possível efeito de mutações encontradas nesta região. 
Realizamos duas construções de 400pb cada, uma representando a região selvagem a 5' a montante do gene TWIST1 e outra com essa mesma região, porém com a presença da mutação encontrada na paciente F1861.1. Ambas foram clonadas no vetor repórter PGL3 para realização do ensaio da luciferase. Esses vetores foram construídos através de PCR com primers com cauda polylinker para as enzimas de restrição Bgl II e Hind III, detalhados na Tabela 5. Para amplificação utilizamos a enzima pfx platinum invitrogem), que é uma polimerase com alta fidelidade. Utilizamos o seguinte programa de amplificação: $95^{\circ} \mathrm{C}-5^{\prime} ; 30$ ciclos de: $94^{\circ} \mathrm{C}-40^{\prime \prime}$, $62^{\circ} \mathrm{C}-45^{\prime \prime}, 72^{\circ} \mathrm{C}-1: 00^{\prime} ; 72^{\circ} \mathrm{C}-10^{\prime}$. Para amplificar a seqüência mutada usamos uma alíquota do DNA do paciente F1861.1 portador dessa mutação (Tabela 1).

\section{sonda selvagem}

F 5'CTCCTCTGCCCCGGGCCCGCGAGGCCACGCGTCGCCGCTCGAGAG 3' R 5'CTCTCGAGCGGCGACGCGTGGCCTCGCGGGCCCGGGGCAGAGGAG 3'

\section{sonda mutada}

F 5'CTCCTCTGCCCCGGGCCCGCGAGGCCAAGCGTCGCCGCTCGAGAG 3' R 5'CTCTCGAGCGGCGACGCTTGGCCTCGCGGGCCCGGGGCAGAGGAG 3'

Figura1- Sondas utilizadas no ensaio de EMSA

Realizamos duas construções de 400pb cada, uma representando a região selvagem a 5' a montante do gene TWIST1 e outra com essa mesma região, porém com a presença da mutação encontrada na amostra da paciente F1861.1. Ambas foram clonadas no vetor repórter PGL3 para realização do ensaio da luciferase. Esses vetores foram construídos através de PCR com primers com cauda polylinker para as enzimas de restrição Bgl II e Hind III, detalhados na Tabela 5. Para amplificação utilizamos a enzima pfx platinum invitrogem), que é uma polimerase com alta fidelidade. Utilizamos o seguinte programa de amplificação: $95^{\circ} \mathrm{C}-5^{\prime} ; 30$ ciclos de: $94^{\circ} \mathrm{C}-40^{\prime \prime}, 62^{\circ} \mathrm{C}-45^{\prime \prime}, 72^{\circ} \mathrm{C}-1: 00^{\prime} ; 72^{\circ} \mathrm{C}-10^{\prime}$. Para amplificar a seqüência mutada usamos uma alíquota do DNA do paciente F1861.1 portador dessa mutação (Tabela $1)$. 
Tabela 2-Em itálico cauda polylinker para BglII(5’) e para HindIII (3’)

\begin{tabular}{|l|l|l|}
\hline $\begin{array}{l}\text { Tamanho } \\
\text { Amplicon }\end{array}$ & FOWARD 5'-3' & REVERSE $\mathbf{5}^{\prime} \mathbf{- 3}^{\prime}$ \\
\hline 400pb & GAAGATCTTCTCACGTCAGGCCAATGAC & CCCAAGCTTGGGCTGCCGGTCTGGCTCTTC \\
\hline
\end{tabular}

O produto da PCR foi digerido com as enzimas BglII e HindIII e, ligado ao vetor. Posteriormente, a construção foi transfectada em bactéria e estas plaqueadas em meio seletivo com ampicilina. Foi realizada PCR das colônias que cresceram, com primers desenhados para o vetor pGL3-Basic (pGL3-Basic F 5'-3': CTA GCA AAA TAG GCT GTC CC e pGL3-Basic R 5'-3': CTT TAT GTT TTT GGC GTC TTC CA). O produto dessa PCR foi visualizado em gel de agarose $0,8 \%$ e analisado juntamente com um marcador de peso molecular para verificar se este possuía o tamanho esperado. Posteriormente, os fragmentos de tamanho esperado foram seqüenciados. Após confirmação da integridade das construções por seqüenciamento automatizado, as colônias adequadas foram semeadas em meio de cultura LB líquido com ampicilina para a realização da extração do vetor por MidiPreps e Minipreps usando o kit da Quiagen ${ }^{\circledR}$.

\section{Transfecção transitória e ensaios de luciferase}

A linhagem celular $293 \mathrm{~T}$ foi plaqueada em placas de 24 poços $\left(2 \mathrm{~cm}^{2}\right.$ de área $)$, na densidade de $10^{5}$ células por poço, um dia antes da transfecção. Um total de $0,2 \mu \mathrm{g}$ de DNA foi usado por poço a ser transfectado, sendo $0,06 \mu \mathrm{g}$ dos vetores repórter pGL-M

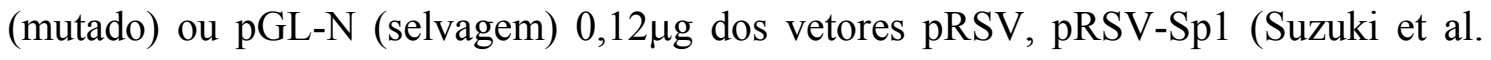
1998) e/ou pBluescript e $0,02 \mu \mathrm{g}$ do vetor pRL-TK, usado para o controle da eficiência da transfecção, conforme mostrado na tabela abaixo (tabela3). O reagente FuGene 6 (Roche) foi usado como agente carreador para as transfecções. Para cada poço, $0,6 \mu 1$ de FuGene 6 foi diluído em $20 \mu 1$ de meio DME, na ausência de SFB. Após 5min, os vetores foram adicionados ao FuGene 6 diluído e incubados por 15min, antes de serem adicionados sobre as células. $24 \mathrm{~h}$ após a transfecção, as células foram lavadas 1x com PBSA e então foram lisadas com $125 \mu l$ da solução de lise PLB (PROMEGA). A 
atividade dos genes repórter luciferase e Renilla luciferase foi medida em um luminômetro, utilizando o sistema Promega (Dual-Luciferase Reporter Assay System).

Tabela 3- Condições de Transfecções

$\begin{array}{ccccc} & \text { pGL3 microG } & \text { pSP1 microG } & \text { pRSV microG } & \text { pRL-TK microG } \\ \mathbf{0 1 : 0 0} & 0,06 & 0,00 & 0,12 & 0,02 \\ \mathbf{0 1 : 0 0 , 5} & 0,06 & 0,03 & 0,09 & 0,02 \\ \mathbf{0 1 : 0 1} & 0,06 & 0,06 & 0,06 & 0,02 \\ \mathbf{0 1 : 0 2} & 0,06 & 0,12 & 0,00 & 0,02\end{array}$

$\begin{array}{ccccc} & \text { pGL3 microG } & \text { pBS microG } & \text { pRSV microG } & \text { pRL-TK microG } \\ \mathbf{0 1 : 0 0} & 0,06 & 0,00 & 0,12 & 0,02 \\ \mathbf{0 1 : 0 0 , 5} & 0,06 & 0,03 & 0,09 & 0,02 \\ \mathbf{0 1 : 0 1} & 0,06 & 0,06 & 0,06 & 0,02 \\ \mathbf{0 1 : 0 2} & 0,06 & 0,12 & 0,00 & 0,02\end{array}$

\section{Resultados}

A análise do sequenciamento do exon 1 em ambas direções revelou a presença das seguintes mutações: p.Pro136Arg no paciente F1714. 1 (NM_000474 c.757), p.Leu 159Pro no paciente F1790 ( T >C NM_000474c.827),e a mutação -18 C>A no paciente F1861.1, na pacinete F2013.1 encontramos a mutação G para T na posição NM_000474 c. 457 gerando o código de parada TGA que culmina com a interrupção da síntese de proteína no aminoácido 36, mutação esta já descrita na literatura (Kress et al. 2005) (fig.2).

A mutação p.Pro136Arg foi encontrada somente na paciente e não em seus pais tratando-se de uma mutação de novo. Já, a mutação p.Leu159Pro, foi encontrada na paciente e também na sua mãe e irmã, ambas afetadas. A mutação $-18 \mathrm{C}>\mathrm{A}$ foi encontrada na paciente, em sua mãe e em sua avó materna, as quais não foram referidas como clinicamente afetadas. A presença destas mutações foi testada em 70 amostras de DNA controle novas utilizando o DHPLC e nenhuma destas foi encontrada. Consideramos essas três mutações como novas. A análise in sílico de uma região a $25 \mathrm{pb}$ na região 5 ' antes do primeiro ATG do gene TWIST1 com e sem a mutação, mostrou a substituição da ligação dos potenciais fatores 
de transcirção Sp1, BTEB, dsc1 and MCBF por NF-1 (fig. 3). A sequência NM_000474 foi utilizada como sequência referência para esta análi -

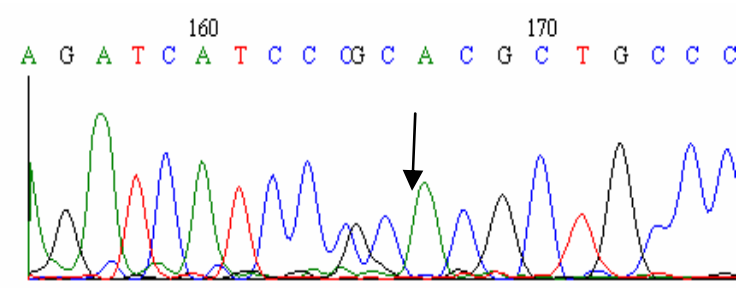

a) Paciente F1714.1- mutação P136R

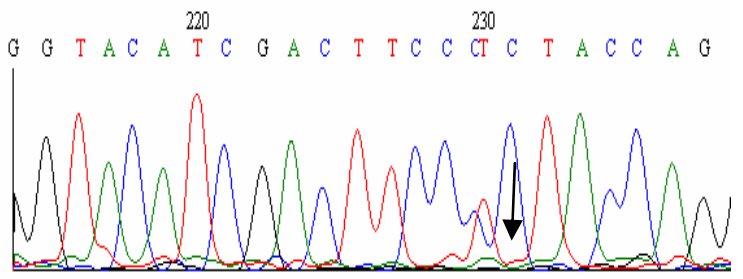

b) Paciente F1790.1-

Mutação L159P

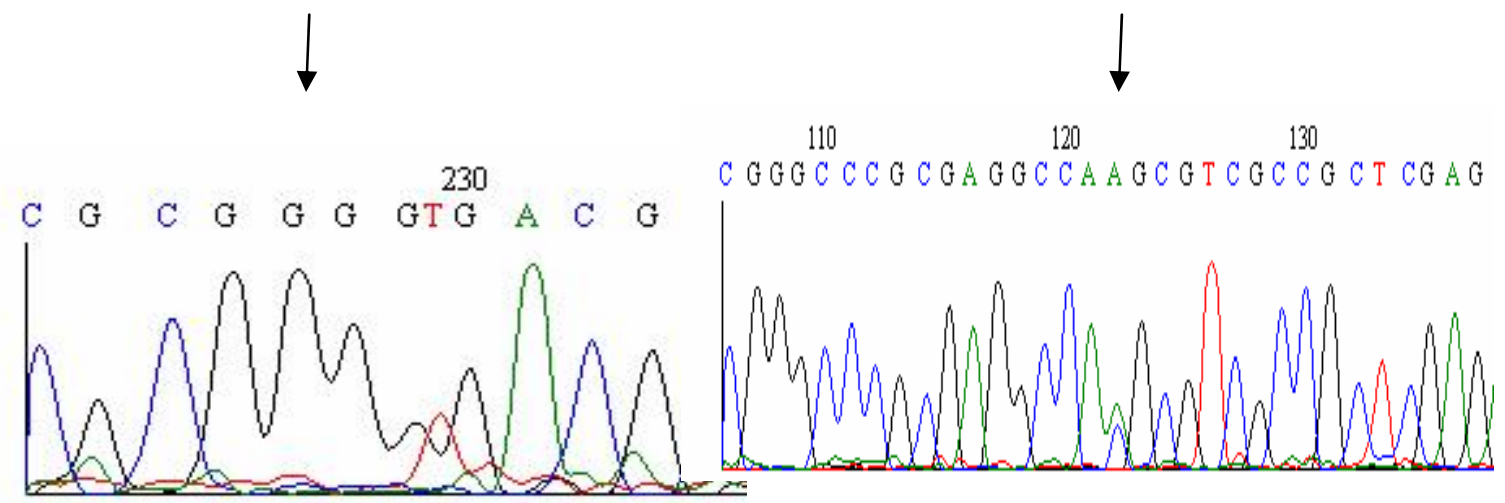

c) Paciente F2013.1 mutação Gly36X d ) Troca de -18 C > A F1861.1

Figura 2: Resultado do sequênciamento mostrando as mutações encontradas no gene TWIST1

\section{Análise da Sequência Selvagem 5’TWIST1}

GAGGC CACGCGTCGC CGCTCGAGAGATG

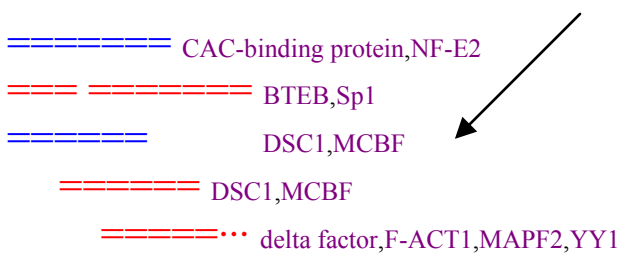




\section{Análise da Sequência mutada 5’TWIST1}

\section{GAG GCAAGCGTCGC CGCTCGAGAGATG}

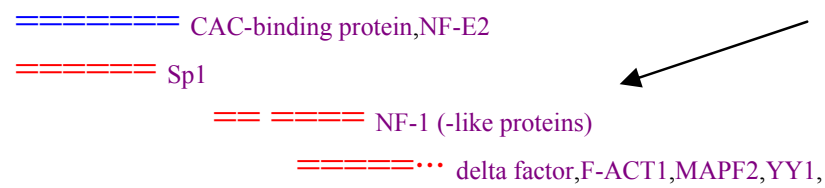

Figura3: Seqüência de nucleotídeos a $5^{\prime}$ do $1^{\circ}$. ATG do gene TWIST, indicando os sítios preditos in silico para interação com fatores de transcrição. As setas mostram as potenciais mudanças de sítios para fatores de transcrição na presença do nucleotídeo C em vez do A na posição -18.

Os experimentos de EMSA foram realizados com o intuito de verificar se o fator de transcrição Sp1 se liga a região onde a mutação está localizada, e caso haja interação, se a mutação altera a afinidade de ligação do fator de transcrição a esta seqüência. Resolvemos testar esse fator, devido ao importante papel desempenhado por este na diferenciação e funcionamento de osteoblasto (Mann et al., 2001, Liu et al. 2005). Os fatores Splgeralmente são importantes para ativação da transcrição de genes com promotores ricos em CG, como parece ser o caso do TWIST1 (Liu et. al, 2005).

Nenhuma alteração no padrão de bandas foi observada com a adição dos anticorpos anti Sp1 (Fig.4), sugerindo que este fator não interage com as sondas em questão nestas condições experimentais. Não podemos, contudo, descartar a possibilidade, de que este fator se ligue à seqüência em questão em condições in vivo. 


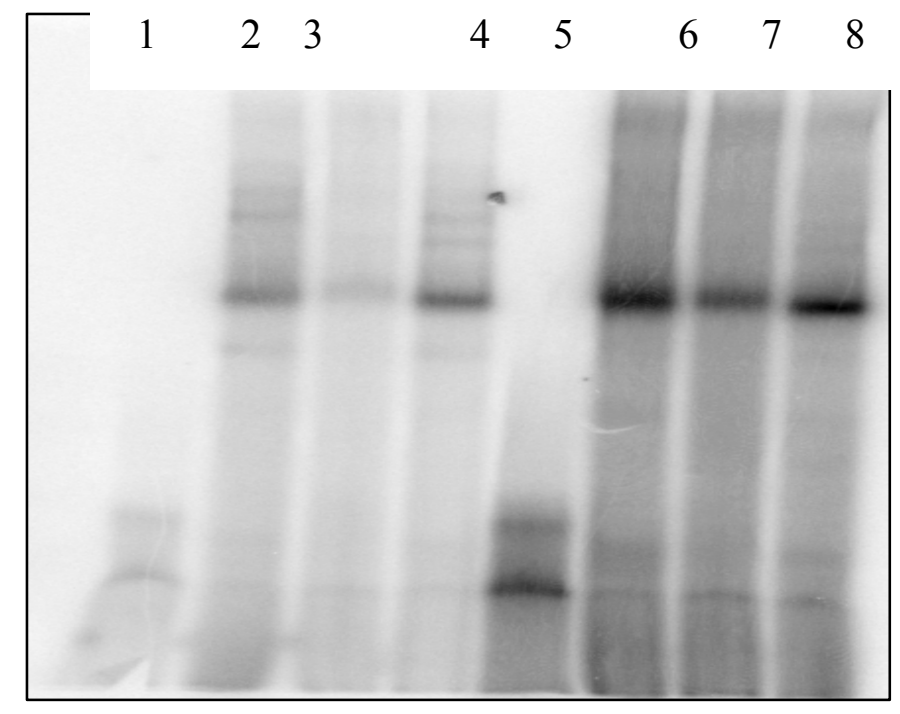

Figura 4. Experimento de Electrophoretic Mobility Shift. 1) Sonda Selvagem livre,2) Extrato nuclear com sonda selvagem, 3)Competidor inespecífico com sonda selvagem, 4) anticorpo sp1, 5) Sonda mutada livre, 6) extrato nuclear mais sonda mutada, 7)competido inespecífico mais sonda mutada, 8) anticorpo sp1 mais sonda mutada

Para testarmos se a mutação é funcional, realizamos ensaios de transfecção em células 293, onde comparamos os níveis de expressão da construção portando a mutação com a construção selvagem medindo a atividade do gene repórter, usando o sistema firefly-luciferase, que já foi descrito previamente. Observamos que não houve diferença entre a atividade da construção selvagem quando comparada com a construção contendo a mutação quando construímos um gráfico com o valor médio de cada uma dessas.

Neste ensaio usamos o vetor vazio PGL3 como controle do experimento (isto é, este por não conter uma região regulatória, expressa menos do que os vetores que contém alguma construção) (figura 5).

Realizamos também a super-expressão do fator Splpara confirmar o papel deste na possível ativação dessa região de 400pb antes do primeiro ATG em células 293.

Sendo esse ensaio mais sensível do que o EMSA por conter uma região maior para ligação de fatores de transcrição (pois a ligação de fatores como sp1 a uma determinada região pode ser influenciada por elementos vizinhos a região em questão) utilizamos na transfecção diferentes concentrações do vetor de expressão PRSV-Sp. O resultado está representado na figura 6 . 
Neste ensaio,comparamos o nível de expressão de cada construção em relação ao aumento da concentração do vetor expressando sp1e também, se havia diferença na expressão de ambas nesta situação (mutada e selvagem). Realizando o cálculo de diferença de médias (Morettin, et al.2006), nota-se que há uma tendência de uma expressão semelhante em ambas construções, sendo que observa-se uma pequena redução quando adicionamos 2 micrograma deste vetor.

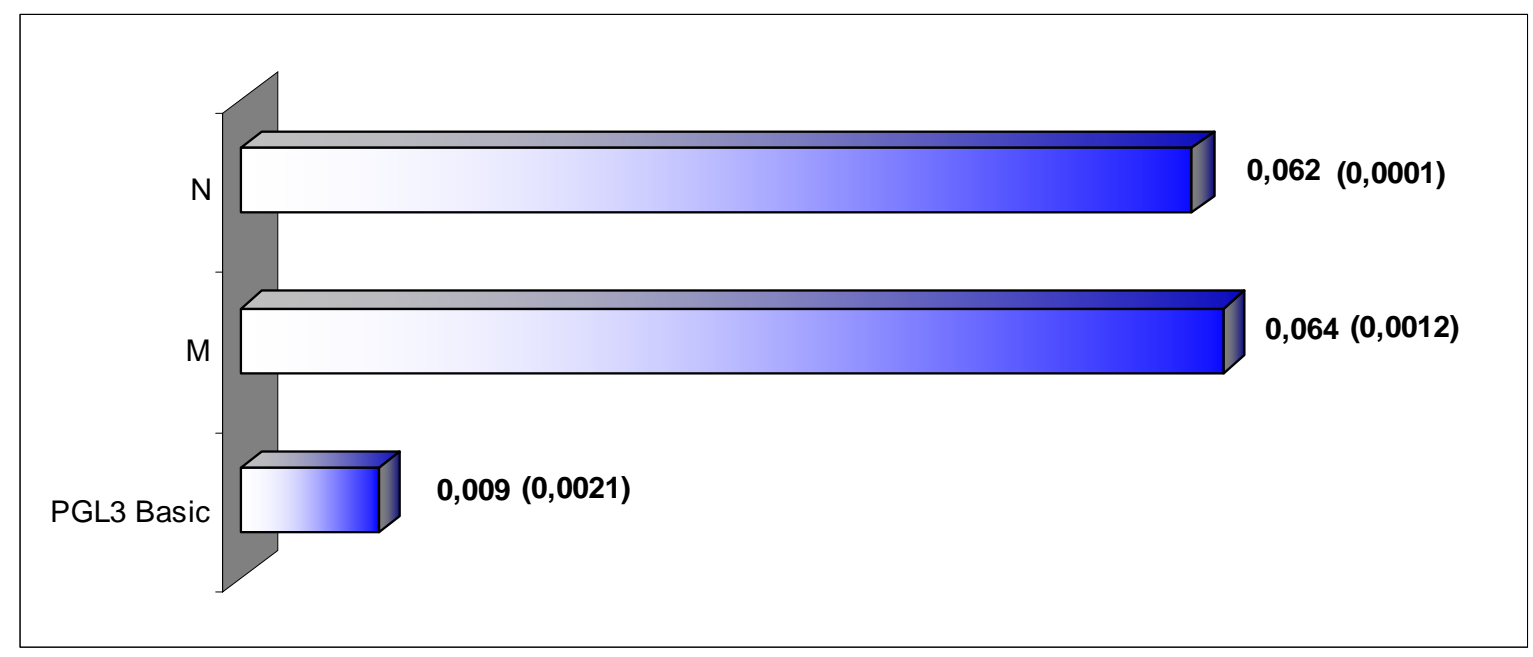

Figura 5- Experimento de Transfecção em células 293 N) construção selvagem ,M) construção contendo a mutação, controle PGL3Basic 


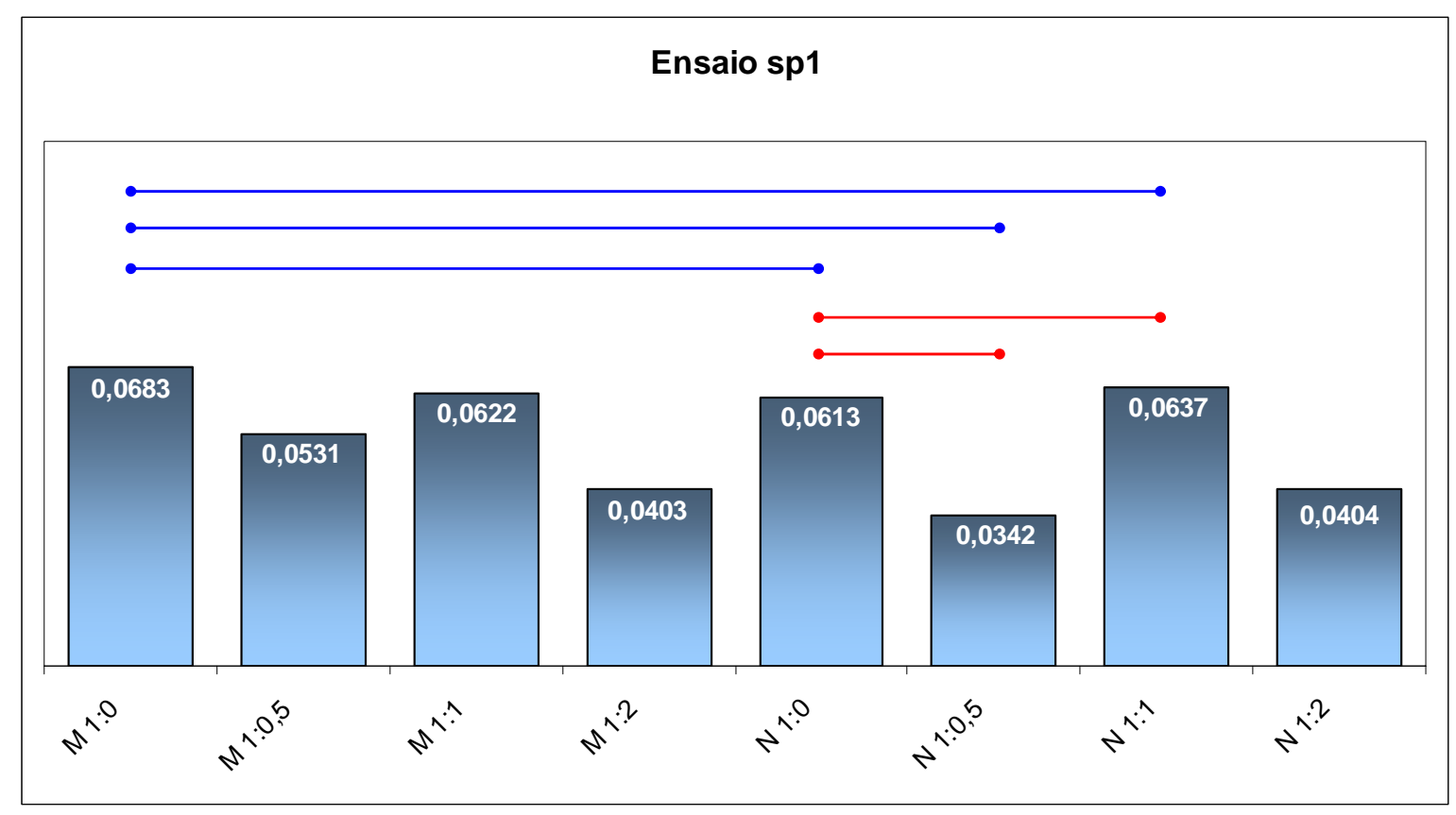

Figura 6- Médias das transfecções dos vetores contendo a seqüência regulatório do gene TWIST1 (seqüência Selvagem $=\mathrm{N}$; seqüência com mutação $=M$ ) com diferentes concentrações do vetor de expressão PRSV-Sp1.

\section{Discussão}

No presente trabalho, dentre os 7 pacientes não relacionados e com diagnóstico de síndrome de Saethre-Chotzen, identificamos 4 mutações no gene TWIST1. Destas 4 mutações, apenas uma delas, p.Gly36X, já foi descrita anteriormente na literatura (Kress et al., 2005).

A mutação p.Pro136Arg é de novo, enquanto a mutação p.Leu159Pro segrega com a doença na família; ambas não foram encontradas em 70 cromossomos normais. Estas observações sugerem que estas duas mutação são patogênicas. A favor desta hipótese, observamos que substituições nestas posições da proteína, respectivamente as substituições Pro136Leu e Leu159Phe, também já foram associadas à síndrome de Saetre-Chotzen (Johnson et al., 1998; El Ghouzzi et al., 1999).

O resíduo 136 está localizado na região helix I da proteína, enquanto o aminoácido 159 está localizado na região helix II da proteína Twist. Estes dois domínios funcionais são fundamentais para a proteína Twist ligar-se ao DNA, e tem-se demonstrado que mutações missense nestes domínios podem levar a alteração da estabilidade da proteína ou da sua capacidade de interação com o DNA. Assim sendo, 
considerando-se que os amino ácidos srginina e prolina, resultantes das substituições 136 e 159, apresentam estrutura e de solubilidade no caso da troca da prolina para a arginina diferente daqueles codificados pela seqüência selvagem, acreditamos que estas alterações levem a perda da capacidade de interação com o DNA.

A mutação $-18 \mathrm{C}>\mathrm{A}$, não descrita anteriormente na literatura, não foi encontrada na população normal. Contudo, está presente em sua mãe e avó materna, ambas clinicamente normais, e não foi detectada em três tios maternos, também clinicamente normais. A Síndrome de Saethre-Chotzen se caracteriza por um grande espectro de variabilidade clínica, intra e interfamiliar. Apesar de ser referida como uma doença com penetrância alta, Funato et al (2005) relataram uma paciente com sinais clínicos da Síndrome e a mutação patogênica p.Arg39Gly no gene TWIST1, cujo pai clinicamente normal é também portador desta mesma alteração. Estes resultados sugeriram portanto, que há outros fatores que junto com esta mutação levam ao surgimento da síndrome.

A posição -18C é altamente conservada entre homem, cão, camundongo e rato e por meio da análise in silico, observamos que está localizada em possíveis sítios de interação com fatores de transcrição. Dentre estes, se destaca o Sp1. Os fatores Sp1geralmente são importantes para ativação da transcrição de genes com promotores ricos em CG, como parece ser o caso do TWIST1 (Liu et. al, 2005). O estudo que realizamos com EMSA, não conseguimos comprovar esta interação.Contudo, os estudos funcionais utilizando vetores repórter, sugere que Sp1 ativa o gene TWIST. Outros estudos funcionais serão importantes para confirmar ou não a possível interação de Sp1 com a região reguladora do gene TWIST1.

$\mathrm{O}$ estudo funcional da mutação $-18 \mathrm{C}>\mathrm{A}$ sugere que o alelo $-18 \mathrm{C}$ não leva a alterações transcricionais significativamente diferentes do alelo -18A. Por outro lado, quando realizamos o ensaio da construção com a seqüência promotora do gene TWIST1 juntamente com a super-expressão do fator de transcrição Sp1, notamos que em algumas situações a seqüência regulatória contendo mutação parece responder diferentemente da seqüência selvagem.

Em conclusão, este estudo possibilitou a identificação de 3 novas mutações no gene TWIST1. Duas destas são patogênicas e corroboram a importância dos resíduos 136 e 159 na função da proteína. O estudo in silico e funcional da região $5^{\prime}$ a montante do $1^{\circ}$. ATG, sugere, que o fator de transcrição $\mathrm{Sp} 1$ interage com a região promotora do gene TWIST1 . Por outro lado, os estudos funcionais da mutação $-18 \mathrm{C}>\mathrm{A}$ não foram conclusivos e 

portanto, novos experimentos terão que ser conduzidos para descartamos ou não a importância desta alteração na causa da doença nesta paciente.

Ainda, os nossos resultados corroboram a existência de heterogeneidade genética associada ao fenótipo de Saethre-Chotzen.

\section{Agradecimentos}

Gostaríamos de agradecer os pacientes e seus familiares pela colaboração.Gostaríamos de agradecer a Senhora Constância Gotto Urbani pela assistência secretarial. Este trabalho foi realizado graças ao suporte financeiro da Fundação de Amparo a Pesquisa do Estado de São Paulo (FAPESP) e pelo Conselho Nacional de Pesquisa (CNPq).

\section{Referências}

Bourgeois P., Bolcato-bellemin A. L, Danse JM, Bloch-Zupan A., Yoshiba K., Stoetzel C., Perrin-Schmitt $\mathrm{P}$. The variable expressivity and incomplete penetrance of the twist-null heterozygous mouse phenotype resemble those of human Saethre-Chotzen syndrome Human Molecular genetics, 6 945-957, 1998.

El Ghouzzi, V.; Le Merrer, M.; Perrin-Schmitt, F.; Lajeunie, E.; Benit, P.; Renier, D.; Bourgeois, P.; Bolcato-Bellemin, A.-L.; Munnich, A.; Bonaventure, J. Mutations of the TWIST gene in the Saethre-Chotzen syndrome. Nature Genet. 15: 42-46, 1997.

Funato N, Ohtani K, Ohyama K, Kuroda T, Nakamura M. Common regulation of growth arrest and differentiation of osteoblasts by helix-loop-helix factors.

Mol Cell Biol. 21(21):7416-28,2001.

Funato N., Twigg S R F, Higashiori N., Ohyama K., Wall S A., Wilkie A. O.M., Nakamura M., Functional analysis of natural mutations in two TWSIT protein motifs. Human Mutation 25, 550-556, 2005.

Howard, T. D.; Paznekas, W. A.; Green, E. D.; Chiang, L. C.; Ma, N.; Ortiz De Luna, R. I.; Delgado, C. G.; Gonzalez-Ramos, M.; Kline, A. D.; Jabs, E. W. Mutations in TWIST, a basic helix-loop-helix transcription factor, in Saethre-Chotzen syndrome. Nature Genet. 15: 36-41, 1997.

Krebs I. Weis I., Hudler M., Rommens J.M., Roth H., Scherer S.W., Tsui L. C., Fuchtbauer E. M., Grzeschik K. H., Tsuji K., Kunz J. Hum Mol. Genet. Translocation breakpoint maps 5 kb 3' from TWIST in a patient affected with Saethre-Chotzen syndrome. 6(7) 1079-86, 1997. 
Kress W., Schropp C. Lieb G., Petersen B., Busse-Ratzka M., Kunz J., Reinhart E., Schafer W. D., Sold J., Hoppe F., Pahnke J., Trusen A., Sorensen N., Krauss J., Collmann H. SaethreChotzen syndrome caused by TWIST 1 gene mutations: functional differentiation from Muenke coronal synostosis syndrome.Eur J Hum Genet. 14(1):39-48,2006.

Liu J, Yang H, Liu W, Cao X, Feng X. Sp1 and Sp3 regulate the basal transcription of receptor activator of nuclear factor kappa $\mathrm{B}$ ligand gene in osteoblasts and bone marrow stromal cells.J Cell Biochem. 1;96(4):716-27, 2005.

Mann V., Hobson E.E., Li B., Stewart T.L., Grant S.F., Robins S.P. Aspden R.M., Ralston S.H. A COL1A1 Sp1 binding site polymorphism predisposes to osteoporotic fracture by affecting bone density and quality. J Clin Invest.107(7):899-907, 2001.

Miller, S.A., Dykes D.D., Polesky H.F. A simple salting out procedure for extracting DNA from human nucleated cells. Nucleic Acids Research 16 (3), 1215. 1988.

Morettin, P. A. et all. Estatística Básica, 5.ed. São Paulo: Ed. Saraiva. 526p. (2006)

Paznekas WA, Cunningham M.L., Howard TD., Korf B.R., Lipson M.H., Grix A.W., Feingold M., Goldberg R., Borochowitz Z., Aleck K., Mulliken J., Yin M., Jabs. E. W. Genetic heterogeneity of Sathre-Chotzen syndrome, due to TWIST and FGFR mutations. Am J. Hum genet. 62(6) 1370-80, 1998.

Read M. Electrophoretic mobility shift assay (EMSA). In: K. Docherty, Editor, Essential Techniques, Wiley \& Sons, NewYork, US 1998.

Suzuki M., Oda E., Nakajima T., Sekiya S., Oda K. Induction of Sp1 in differentiating human embryonal carcinoma cells triggers transcription of the fibronectin gene. Molecular and cellular biology, 3010-3020, 1998.

Wang S.M., Coljee V.W., Pignolo R.J., Rotenberg M.O., Cristofalo V.J., Sierra F. Cloning of the human twist gene: its expression is retained in adult mesodermally-derived tissues. Gene. 10;187(1):83-92,1997.

Warren S. M. \& Longaker M. T. The pathogenesis of craniosynostosis in the fetus. Yonsei Medical Journal 42(6), 646-659, 2001 
Yousfi M., Lasmole F. Marie P.J.TWIST inactivation reduces CBFA1/RUNX2 expression and DNA binding to the osteocalcin promoter in osteoblasts.Biochem Biophys Res Commun 27;297(3):641-4. 2003 
CAPÍTULO VI

\section{DISCUSSÃO E CONCLUSÕES}


Este trabalho representa um esforço para aumentar a compreensão dos mecanismos moleculares que envolvem a fusão precoce das suturas cranianas. Apesar dos grandes avanços obtidos na última década com a identificação de genes associados ás algumas síndromes de craniossinostose, existem ainda várias respostas a serem respondidas, tais como: a) pacientes com formas graves de síndrome de Pfeiffer são sempre causadas pelas mesmas mutações em FGFR2? ; b) há outros genes envolvidos com as craniossinostoses sindrômicas? ; c) mutações em regiões regulatórias podem causar craniossinostose?

Primeiramente, estudamos o gene TWIST1 e as principais regiões dos genes FGFR1, FGFR2, FGFR3 envolvidas com craniossinostoses sindrômicas em 68 amostras de DNA provenientes de pacientes com craniossinostoses sindrômicas não relacionados.

No capítulo III (Nova evidência de que mutações no gene FGFR2 causam craniossinostose sindrômica com eversão sacroccigeal) descrevemos uma paciente com quadro clínico de Pfeiffer tipo III , que apresenta algumas características clínicas raras hipoplasia do corpo caloso, a qual geralmente está associada à Síndrome de Apert e , eversão sacroccigeal. Verificamos que o quadro clínico da paciente é decorrente da mutação Trp290Cys, o que corrobora os dados da literatura que esta mutação está associada a casos graves de Síndrome de Pfeiffer. Eversão sacroccigeal, uma anomalia muito rara, foi descrita também em outros 5 pacientes com craniossinostose sindrômica. Todos estes casos, incluindo o nosso, apresentam mutações no gene FGFR2 (Gonzalez et al. 2005; Lapunzina et al. 2005, Lajeunie et al. 2006). e também comprometimento de traquéia. Especulamos então que estes dois defeitos possuem uma alteração comum na via de sinalização FGFR/FGF. Ainda, a presença de eversão sacroccigeal não parece estar relacionada a um único tipo de mutação no gene FGFR2.

No capítulo IV (Análise dos genes FGF3 e FGF4 em pacientes com craniossinostose sindrômica) apresentamos a triagem de mutações dos genes FGF3 e FGF4, que foram considerados candidatos funcionais para craniossinostoses sindrômicas. Nós não identificamos nenhuma mutação patogênica na região codificadora, somente alguns polimorfismos que também foram encontrados em nossa amostra controle. Como ressaltado neste capítulo, não identificamos nenhuma mutação 
rara que pudesse explicar o fenótipo. Interessantemente, identificamos recentemente em nosso laboratório um paciente com craniossinostose sindrômica e duplicação da região do cromossomo 11, que contem os 
genes FGF3 e FGF4. Considerando-se os dados clínicos, as possíveis funções de FGF3 e FGF4, e os dados do camundongo com craniossinostose de várias suturas e aumento de expressão de Fgf3 e Fgf4 (Carlton et al. 1998), sugerimos que estes dois genes estão envolvidos com craniossinostose (Jehee, 2005 (tese); Jehee et al., 2006). Como o efeito funcional de duplicações é similar ao de mutações que leva a ganho de funções, é possível que duplicações gênicas em vez de mutações pontuais sejam responsáveis por um quadro sindrômico de craniossinostose e isto explicaria os resultados negativos obtidos na triagem do pacientes selecionados.

No capítulo V(Análise do gene TWIST1 em pacientes com síndrome de SaethreChotzen: descrição de três novas mutações) falamos do estudo molecular do gene TWIST1 que realizamos em sete amostras de DNA de pacientes caracterizados clinicamente como afetados pela Síndrome de Saethre-Chotzen. A análise molecular do gene TWIST1 nos possibilitou identificar nas amostras dos afetados as seguintes mutações que consideramos como novas: Pro136Arg, Leu159Pro e -18 C>A que está localizada na região 5' antes do primeiro ATG. Identificamos também em nossa amostra, uma mutação que leva a um códon de parada ,interrompendo a síntese da proteína no aminoácido 36 (Kress et al. 2005). Não realizamos estudo funcional das duas primeiras mutações devido a evidências na literatura de alteração da região dos aminoácidos correspondentes a estas com a doença (El Ghouzzi et al. 1999, El Ghouzzi et al. 2000). Por outro lado, realizamos o ensaio funcional da mutação encontrada a 5 , com intuito de verificar se esta causa um perfil diferente de expressão do gene. Fizemos ensaios de transfecção em células 293 onde comparamos níveis de expressão da construção selvagem com a mutada. Não houve diferença significativa. Como, tínhamos previsto a perda de um fator sp1 em função da presença da mutação, realizamos um experimento, onde superexpressamos essa proteína e co-transfectamos juntamente com a seqüência mutada e com a seqüência selvagem em diferentes experimentos. Vimos que a construção com a seqüência portadora da mutação tendeu a expressar menos do que a construção selvagem. Estes resultados sugerem que a mutação possa ter efeito funcional, contudo, parece ser insuficiente para causar o quadro clínico da paciente.

Em conclusão, verificamos que a mutação p.Trp290Cys está relacionada a uma forma grave de Pfeiffer tipo III que apresenta eversão sacrococcigeal. Verificamos que mutações pontuais nos genes FGF3/FGF4 não estão ligadas a craniossinostoses sindrômicas. Em relação ao gene TWIST1, identificamos duas mutações novas que 
julgamos serem responsáveis pelo fenótipo dos pacientes e uma outra mutação patogência, que já havia sido descrita na literatura. Uma mutação na região 5' a montante do primeiro ATG foi também estudada e os estudos funcionais sugerem que ela possa ter um papel funcional, mas não suficiente para causar o fenótipo. 


\section{CAPÍTULO VII}

\section{Referências}

Afanador, E. Yokozeki M., Oba Y., Kitase Y., Takahashi T., Kudo A., Moriyama K. Messenger RNA expresión of periostio and Twist transiently decrease by occlusal hypofunction in Mouse periodontal ligament. 50, 1023-1031,2005.

Amano S., Tatsumi K., Tanabe N., Kasahara Y., Kurosu K., Takiguchi Y., Kasuda Y., Kimura S., Kuriyama T. Polymorphism of the promoter region of prostacyclin synthase gene in chronic thromboembolic pulmonary hypertension. Respirology 9, 184-189, 2004.

Baroni, T., C. Lilli, et al. Crouzon's syndrome: differential in vitro secretion of bFGF, TGFbeta I isoforms and extracellular matrix macromolecules in patients with FGFR2 gene mutation. Cytokine, v.19, n.2, Jul 21, p.94-101. 2002

Bellus GA, Gaundez K., Zackai EH, Clarke LA, Szabo LA, Francomano CA, Muenke M. Identical mutations in three different fibroblast growth factor receptor genes in autosomal dominat craniosynostosis síndromes. Nature Genetics 14(2): 174-6,1996.

Berry, D., Shriver Z., Natke B., Kwan C.P, Venkataraman G., Sasisekharan R. Heparan sulphate glycosaminoglycans derived from endothelial cells and smooth muscle cells differentially modulate fibroblast growth factor-2 biological activity through fibroblast growth factor receptor-1. Biochemistry Journal 373 241-249, 2003.

Boilly, B., Vercoutter-Edouart A.S., Nurcombe V., Bourhis X.L. FGF signals for cell proliferation and migration through different pathways. Cytokine Growth Factor Reviews 11 295-302, 2000.

Bourgeois P., Bolcato-bellemin A. L, Danse JM, Bloch-Zupan A., Yoshiba K., Stoetzel C., Perrin-Schmitt P. The variable expressivity and incomplete penetrance of the twist-null heterozygous mouse phenotype resemble those of human Saethre-Chotzen syndrome Human Molecular genetics, 6 945-957, 1998.

Brophy V.H., Hastings M.D., Clendenning J.B., Richter R.J., Jarvik G.P., Furlong C. E. Polymorphisms in the human paraoxonase (PON1) promoter. Pharmacogenetics 11, 77-84, 2001. 
Carlton, M. B., Colledge W.H., Evans M. Crouzon-like craniofacial dysmorphology in the mouse is caused by an insertional mutation at the Fgf3/Fgf4 locus. Developmental Dynamics, 212,242-9, 1998.

Chan, C. T. e P. Thorogood. Pleiotropic features of syndromic craniosynostoses correlate with differential expression of fibroblast growth factor receptors 1 and 2 during human craniofacial development. Pediatr Res, v.45, n.1, Jan, p.46-53. 1999.

Chave K.J., Ryan T.J., Chmura S.E, Galivan, J. Identification of single nucleotide polymorphisms in the human $\gamma$-glutamyl hydrolase gene and characterization of promoter polymorphisms. Gene 319, 167-175, 2003.

Cohen MM Jr, Kreiborg S. New indirect method for estimating the birth prevalence of the Apert syndrome. Int J Oral Maxillofac Surg. Apr;21(2):107-9 1992.

Cohen M M Jr., Craniosynostoses: phenotypic/molecular correlations. American Journal of Medical Genetics 56, 334-339, 1995.

Cohen Jr. MM. Syndromes with craniosynostosis. In: Cohen Jr MM, Maclean RE. (eds) Craniosynostosis: Diagnosis, Evaluation, and Management. New York : Oxford University Press,; 309-441, 2000.

Cohen MM JR. Crouzon Syndrome. In: Epstein CJ, Ericson RP, Wynshaw-Boris A (eds). Inborn Errors of Development - the molecular basis of clinical disorders of morphogenesis. New York: Oxford University Press, 361-365, 2004.

Cohen MM JR. Apert Syndrome. In: Epstein CJ, Ericson RP, Wynshaw-Boris A (eds). Inborn Errors of Development - the molecular basis of clinical disorders of morphogenesis. New York: Oxford University Press, 316-350, 2004.

Cohen Jr. MM. FGfs/FGFRs and Associated Disorders. In: Epstein CJ, Ericson RP, WynshawBoris A (eds). Inborn Erros of Development-the molecular basis of clinical disorders of morphogenesis. New York: Oxford University Press, 380-397, 2004.

De Moerlooze, L. B., Spencer-Dene B., Revest J.M., Hajihosseini M., Rosewell I., Dickson C. An important role for the IIIb isoform of fibroblast growth factor receptor 2 (FGFR2) in mesenchymal-epithelial signalling during mouse organogenesis. Development 127, 483-92, 2000.

Dickson, C., Spencer-Dene B., Dillon C., Fantl V. Tyrosine kinase signalling in breast cancer: fibroblast growth factors and their receptors. Breast Cancer Research 2,191-6, 2000.

Dunnen J.T. \& Antonarakis E., Nomenclature for the description of human sequence variations. Hum Genet 109: 121-124, 2001.

El Ghouzzi, V.; Le Merrer, M.; Perrin-Schmitt, F.; Lajeunie, E.; Benit, P.; Renier, D.; Bourgeois, P.; Bolcato-Bellemin, A.-L.; Munnich, A.; Bonaventure, J. Mutations of the TWIST gene in the Saethre-Chotzen syndrome. Nature Genet. 15: 42-46, 1997.

EL Ghouzzi V, Lajeunie E, Lemer M., Cormier-Darie V., Renier D., Munnich A., Bonaventure J. Mutations within or upstream of the basic helix-loop-helix domain of the TWIST gene are specific to Saethre-Chotzen syndrome.Eur J Hum Genet. 7 (1):27-33. 1999. 
EL Ghouzzi V., Legeai-Mallet L., Benoist-Lasselin C., Lajeunie E., Renier D., Munnich A., Bonaventure J. Saethre-Chotzen mutations cause TWIST protein degradation or impaired nuclear location, Hum Mol Genet. 22;9(5):813-9.,2000.

EL Ghouzzi V., Legeai-Mallet L., Benoist-Lasselin C., Lajeunie E., Renier D., Munnich A., Bonaventure J. Mutations in the basic domain and the loop-helix II junction of TWIST abolish DNA binding in Saetre-Chotzen syndrome, FEBS Letters 492 ,112-118, 2001. 
Eliya-Rannan SV, Taylor IB, De Heer IM, Van Den Ouweland AM, Wall SA, Wilkie AO. Paternal origin of FGFR3 mutations in Muenke-type craniosynostosis. Human Genetics 115 (3):200-7 2004.

Eswarakumar VP, Lax I, Schlessinger J. Cellular signaling by fibroblast growth factor receptors. Citokine Growth factor rev. 16(2) 139-49, 2005.

Fragale, A., Tartaglia M., Bernardini S., Di Stasi A.M. M., Di Rocco C., Velardi F., Teti A., Battaglia P.A., Migliaccio S. Decreased proliferation and altered differentiation in osteoblasts from genetically and clinically distinct craniosynostotic disorders. American Journal of Pathology.154 (5) 1465-1477,1999.

Frith, M.C.; Li, M.C. and Weng , Z. - Cluster-Buster: finding dense clusters of motifs in DNA sequences. Nucleic Acids Res 31:3666-3668,2003.

Fujisawa, H., Hasegawa M., Kida S., Yamashita J. A novel fibroblast growth factor receptor 2 mutation in Crouzon syndrome associated with Chiari type I malformation and syringomyelia. Journal Neurosurg 97, 396-400, 2002.

Funato N, Ohtani K, Ohyama K, Kuroda T, Nakamura M. Common regulation of growth arrest and differentiation of osteoblasts by helix-loop-helix factors.Mol Cell Biol. 21(21):741628,2001 .

Funato N., Twigg S R F, Higashiori N., Ohyama K., Wall S A., Wilkie A. O.M., Nakamura M., Functional analysis of natural mutations in two TWSIT protein motifs. Human Mutation 25, 550-556, 2005.

Gachot-Neveu H., Stoetzel C., Quillet R., Dollfus H., Perrin-Schmitt F. Natural Twist protein variants in a panel of eleven non-human primates: possible implications of twist gene-tree for primate species-tree. 212, 496-503, 2002.

Gonzales M., Hewertz S., Martinovic J., Delahaye S., Bazin A., Loget P., Pasquier L., Merrer M., Bonaventure J. Vertebral anomalies and cartilaginous tracheal sleeve in three in three patients with Pfeiffer Syndrome carrying the S351C FGFR2 mutation Clinical Genetics 68:179181,2005 .

Holleville, N., Quilhac A., Bountoux M., Monsoro-Burq AH., BMP signals regulate Dlx5 during early avian skull development. Development Biology 257 (1)177-189, 2003.

Howard, T. D.; Paznekas, W. A.; Green, E. D.; Chiang, L. C.; Ma, N.; Ortiz De Luna, R. I.; Delgado, C. G.; Gonzalez-Ramos, M.; Kline, A. D.; Jabs, E. W. Mutations in TWIST, a basic helix-loop-helix transcription factor, in Saethre-Chotzen syndrome. Nature Genet. 15: 36-41, 1997.

Iseki, S., Wilkie, A.O.M., Morris-Kay G.M. Fgfr1 and Fgfr2 have distinct differentiation- and proliferation-related roles in the developing mouse skull vault. Development 126 5611-5620, 1999. 
Ibrahimi, O. A., Zhang F., Eliseenkova A.V. , Linhardt R. J., Mohammadi M. Proline to arginine mutations in FGF receptors 1 and 3 result in Pfeiffer and Muenke craniosynostosis syndromes through enhancement of FGF binding affinity. Human Molecular Genetics 13(1): 6978, 2004.

Johnson D., Hoisley SW., Moloney DM., Oldridge M, Twigg SR, Walsh S., Barrow M., Njolstad PR, Kunz J., Ashworth GJ, Wall SA., Kearney L., Wilkie AO. A comprehensive screen for TWIST mutations in patients with craniosynostosis identifies a new microdeletion syndromeof chromosome band 7p21.1. American Journal Human Genetics 63(5), 1282-93, 1998.

Kan S. H., Elanko N., Johnson D.,Cornejo-Roldan, L., Cook J., Reich E. W, Tomkins S., Verloes A., Twigg S. R. F., Rannan-Eliya S., McDonald-McGinn D. M., Zackai E. H., Wall, S. A., Muenke M., Wilkie A. O. M. Genomic screening of fibroblast growth-factor receptor 2 reveals a wide spectrum of mutations in patients with syndromic craniosynostosis.American Journal Human Genetics 70, 472-486, 2002.

Kim, H. J., Rice D.P., Kettunen P.J., Thesleff I. FGF-, BMP- and Shh-mediated signalling pathways in the regulation of cranial suture morphogenesis and calvarial bone development. Development 125(7), 1241-1251, 1998.

Krebs I. Weis I., Hudler M., Rommens J.M., Roth H., Scherer S.W., Tsui L. C., Fuchtbauer E. M., Grzeschik K. H., Tsuji K., Kunz J. Hum Mol. Genet. Translocation breakpoint maps 5 kb 3' from TWIST in a patient affected with Saethre-Chotzen syndrome. 6(7) 1079-86, 1997.

Kress, W., Collmann H., Busse M., Keller-Halliger B., Mueller C.R. Clustering of FGFR2 gene mutations inpatients with Pfeiffer and Crouzon syndromes (FGFR2-associated craniosynostoses). Cytogenetics Cell Genetics 91,134-137, 2000.

Kress W., Schropp C. Lieb G., Petersen B., Busse-Ratzka M., Kunz J., Reinhart E., Schafer W. D., Sold J., Hoppe F., Pahnke J., Trusen A., Sorensen N., Krauss J., Collmann H. SaethreChotzen syndrome caused by TWIST 1 gene mutations: functional differentiation from Muenke coronal synostosis syndrome.Eur J Hum Genet. 14(1):39-48,2006.

Kuklin, A., Munson, K., Gjerde, D., Haefele, R., Taylor, P. Detection of single-nucleotide polymorphisms with the WAVE DNA fragment analysis system Genet Test 1(3): 201-206,1997.

Lajeunie E, Heuertz S, El Ghouzzi V, Martinovic J, Renier D, Le Merrer M, Bonaventure J.Mutation screening in patients with syndromic craniosynostoses indicates that a limited number of recurrent FGFR2 mutations accounts for severe forms of Pfeiffer syndrome. Eur $\mathrm{J}$ Hum Genet. 1-10,2006.

Lapunzina, P., Fernández A., Sánchez R., Delicado, A., Pipaon, M. S., Pajares, I.L., Molano, J. A novel insertion in the FGFR2 gene in a patient with Crouzon phenotype and sacroccoccygeal eversion. Birth Defects Research, 73, 61-64,2005.

Lenine M. \& Tjian, R. Transcription regulation and animal diversity. Nature 424, 147-151, 2003

Lian, J.B., Stein, J.L, et al. Runx2/Cbfa1 functions: Diverse regulation of gene transcription by chromatin remodeling and co-regulatory protein interactions._Conetv. Tissue Resarch, 44 (1), 141-148, 2003.. 
Liu J, Yang H, Liu W, Cao X, Feng X. Sp1 and Sp3 regulate the basal transcription of receptor activator of nuclear factor kappa B ligand gene in osteoblasts and bone marrow stromal cells.J Cell Biochem. 1;96(4):716-27, 2005.

Mann V., Hobson E.E., Li B., Stewart T.L., Grant S.F., Robins S.P. Aspden R.M., Ralston S.H. A COL1A1 Sp1 binding site polymorphism predisposes to osteoporotic fracture by affecting bone density and quality. J Clin Invest.107(7):899-907, 2001.

McIntosh I.,. Bellus G.A., Jabs E. W. The pleiotropic effects of fibroblast growth factor receptors in mammalian development. Cell Structure And Function 25(2): 85-96, 2000. 
Miller, S.A., Dykes D.D., Polesky H.F. A simple salting out procedure for extracting DNA from human nucleated cells. Nucleic Acids Research 16 (3), 1215. 1988.

Morris-Kay GM \& Wilkie A.O.M. Growth of the normal skull vault and its alteration in craniosynostosis: insights from human genetics and experimental studies. Journal Anatomy. 2005 Nov;207(5):637-53, 2005

Nishioka Y., Sagae S., Nishikawa A., Ishioka S.I., Kudo R. A relationship between matriz metalloproteinase-1 (MMP-1) promoter polymorphism and cervical cancer progression. Cancer Letters 200, 49-55, 2003.

Paznekas WA, Cunningham M.L., Howard TD., Korf B.R., Lipson M.H., Grix A.W., Feingold M., Goldberg R., Borochowitz Z., Aleck K., Mulliken J., Yin M., Jabs. E. W. Genetic heterogeneity of Sathre-Chotzen syndrome, due to TWIST and FGFR mutations. Am J. Hum genet. 62(6) 1370-80, 1998.

Pesole G. \& Liuni S. Internet resources for the functional analysis of 5' and 3' untranslated regions of eukaryotic mRNA. Trends Genet. 15(9)378, 1999.

Oefner PJ, Underhill PA Comparative DNA sequencing by denaturing high-performance liquid chromatography (DHPLC) Am J Hum Genet 57: A266.

Oefner PJ, Underhill PA Detection of nucleic acid heteroduplex molecules by denaturinghighperformance liquid chromatography and methods for comparative sequencing. US patents 5 , 795, 976, 1998.

Oefner PJ, Underhill PA DNA mutation detection using denaturing high-performance liquid chromatography (DHPLC) In: Dracopoli, N.C., Haines, J., Korf, B.R., Morton, C., Seidman, C.E., Seidman, J.G., Moir, D.T., Smith, D.R. ed. Current protocols in human genetics. New York: Wiley-Interscience. Suppl. 19. p.7.10.1-7.10.12,1999.

Ornitz, D. M. \& Marie P. J.. FGF signaling pathways in endochondral and intramembranous bone development and human genetic disease. Genes in Development 16 (12), 1446-1465, 2002.

Passos-Bueno M.R., Wilcox W.R., Jabs E.W., Sertie A.L, Kitoh H. Clinical spectrum of fibroblast growth factor receptor mutations. Humam Mutation 14,115-125, 1999.

Passos-Bueno, M. R., Armelin L. M. Alonso L.G., Neustein I., Sertie A.L., Abe K., Pavanello R.C., Elkis L.C., Koiffmann C.P.Craniosynostosis associated with ocular and distal limb defects is very likely caused by mutations in a gene different from FGFR, TWIST, and MSX2. American Journal of Medical genetics 113, 200-206, 2002

Read M. Electrophoretic mobility shift assay (EMSA). In: K. Docherty, Editor, Essential Techniques, Wiley \& Sons, NewYork, US 1998.

R., Tognon M., Carinci P. A regulatory role of fibroblast growth factor in the expression of decorin, biglycan, betaglycan and syndecan in osteoblasts from patients with Crouzon's syndrome. European Journal of Cell Biology,78, 323-330, 1999 
Rice D.P., Aberg T., Chan Y., Tang Z., Kettunen P.J., Pakarinen L., Maxson R.E., Thesleff I.I Development, integration of FGF and TWIST in calvarial bone and suture development. 127(9): $1845-55,2000$.

Ricol, D.; Cappellen D., Marjou A., Gil-Diez-de-Medina S., Girault JM., Yoshida T., Ferry G., Tucker G., Poupon M.F., Chopin D., Thiery J.P. Radvanyi F. Tumour suppressive properties of fibroblast growth factor receptor 2-IIIb in human bladder cancer. Oncogene 18, 7234-7243, 1999.

Scheid S.C., Spector A.R., Luft J. D. Tracheal cartilaginous sleeve in Crouzon syndrome. International journal of pediatric Otorhinolaryngology 65, 147-152, 2002.

Suzuki M., Oda E., Nakajima T., Sekiya S., Oda K. Induction of Sp1 in differentiating human embryonal carcinoma cells triggers transcription of the fibronectin gene. Molecular and cellular biology, 3010-3020, 1998.

Tartaglia, M., Valeri, S., Velardi, F., Di Rocco, C., Battaglia, P.A. 1997. Trp290Cys mutation in exon IIIa of the fibroblast growth factor receptor 2 (FGFR2) gene is associated with Pfeiffer syndrome. Human Genetics, 99:602-606.

Wang S.M., Coljee V.W., Pignolo R.J., Rotenberg M.O., Cristofalo V.J., Sierra F. Cloning of the human twist gene: its expression is retained in adult mesodermally-derived tissues. Gene. 10;187(1):83-92,1997.

Warren S. M. \& Longaker M. T. The pathogenesis of craniosynostosis in the fetus. Yonsei Medical Journal 42(6), 646-659, 2001.

Warren, S.M., Brunet L.J., Harland R. M., Economides A.N., Longaker M.T. The BMP antagonist noggin regulates cranial suture fusion. Nature, 6932 (422), 625-629, 2003.

Wilkie, A. O. M. Craniosynostosis: genes and mechanisms. Hum. Molec. Genet. 6: 1647-1656, 1997.

Wilkie A.O.M, Morris-Kay GM. Genetics of craniofacial development and malformation. Nature Revies Genetics.2(6), 458-468, 2001.

Xiao, W., Oefner, P.J. Denaturing High-Performance Liquid Chromatography A Review Hum. Mutat 17:439-474,2001..

Yang J. Mani S.A., Donaher J.L., Ramaswamy S., Itzykson R.A., Come C., Savagner P., Gitelman I., Richardson A., Weinberg R. A. Twist, a master regulator of morphogenesis, plays an essential role in tumor metastasis. Cell 117,927-939, 2004.

Yousfi M., Lasmole F. Marie P.J.TWIST inactivation reduces CBFA1/RUNX2 expression and DNA binding to the osteocalcin promoter in osteoblasts.Biochem Biophys Res Commun 27;297(3):641-4. 2003

Zhang Y., Hayes A., Pritchard A., Thaker U., Haque M. S., Lemmon H., Harris J., Cumming A., Lambert J.C, Chartier-Harlin M.C, Clair, D., Iwatsubo, T., Mann D.M., Lendon, C. L. 
Interleukin-6 promoter polymorphism: risk and pathology of Alzheimer 's disease. Neuroscience Letters 362, 99-102, 2004.

\section{Anexo-I}




\section{Anexo II}

Tabela1. Listagem dos pacientes estudados nesse trabalho

\begin{tabular}{|c|c|c|c|c|c|}
\hline $\begin{array}{l}\text { Registro do } \\
\text { Propósito }\end{array}$ & Doença & $\begin{array}{l}\text { Mutação } \\
\text { encontrada }\end{array}$ & Gene & Referência: & $\begin{array}{l}\text { Número de } \\
\text { portadores da } \\
\text { mutação na } \\
\text { família }\end{array}$ \\
\hline CR4 & Pfeiffer & Não & $*$ & * & $*$ \\
\hline CR28 & Crouzon & Não & $*$ & $*$ & $*$ \\
\hline CR36 & Crouzon & Não & $*$ & * & $*$ \\
\hline CR42 & Apert & Não & $*$ & $*$ & $*$ \\
\hline CR92 & $\begin{array}{l}\text { Craniossinostose } \\
\text { sindrômica }\end{array}$ & Não & $*$ & $*$ & $*$ \\
\hline
\end{tabular}




\begin{tabular}{|c|c|c|c|c|c|}
\hline CR125 & Pfeiffer & Não & * & $*$ & * \\
\hline CR154 & trigonocefalia & Não & & & \\
\hline CR156 & $\begin{array}{l}\text { Craniossinostose } \\
\text { sindrômica }\end{array}$ & Não & & & \\
\hline CR191 & plagiocefalia & Não & $*$ & $*$ & $*$ \\
\hline CR196 & Crouzon & Não & $*$ & $*$ & $*$ \\
\hline CR197 & $\begin{array}{l}\text { Craniossinostose } \\
\text { sindrômica }\end{array}$ & Não & $*$ & $*$ & * \\
\hline CR203 & Pfeiffer & Não & $*$ & $*$ & * \\
\hline CR218 & Crouzon & Não & $*$ & $*$ & $*$ \\
\hline CR223 & $\begin{array}{l}\text { Craniossinostose } \\
\text { sindrômica }\end{array}$ & Não & $*$ & $*$ & $*$ \\
\hline CR224 & Pfeiffer & Não & & * & * \\
\hline CR225 & $\begin{array}{l}\text { Craniossinostose } \\
\text { sindrômica }\end{array}$ & Não & & & \\
\hline CR227 & Pfeiffer & Não & * & * & * \\
\hline CR246 & $\begin{array}{l}\text { Craniossinostose } \\
\text { sindrômica }\end{array}$ & Não & & & \\
\hline CR254 & Trigonocefalia & Não & & & \\
\hline CR256 & Trigonocefalia & Não & & & \\
\hline CR277.1 & Trigonocefalia & Não & $*$ & $*$ & $*$ \\
\hline CR302 & Trigonocefalia & Não & $*$ & $*$ & $*$ \\
\hline CR304 & Trigonocefalia & Não & $*$ & $*$ & $*$ \\
\hline CR309 & Trigonocefalia & Não & $*$ & $*$ & $*$ \\
\hline CR315 & $\begin{array}{l}\text { Craniossinostose } \\
\text { sindrômica }\end{array}$ & Não & $*$ & * & $*$ \\
\hline CR320 & $\begin{array}{l}\text { Craniossinostose } \\
\text { sindrômica }\end{array}$ & Não & & & \\
\hline CR321 & $\begin{array}{l}\text { Craniossinostose } \\
\text { sindrômica }\end{array}$ & Não & & & \\
\hline CR322 & $\begin{array}{l}\text { Craniossinostose } \\
\text { sindrômica }\end{array}$ & Não & & & \\
\hline CR323 & $\begin{array}{l}\text { Craniossinostose } \\
\text { sindrômica }\end{array}$ & Não & & & \\
\hline CR324 & $\begin{array}{l}\text { Craniossinostose } \\
\text { sindrômica }\end{array}$ & Não & & & \\
\hline CR326 & $\begin{array}{l}\text { Craniossinostose } \\
\text { sindrômica }\end{array}$ & Não & & & \\
\hline CR327 & $\begin{array}{l}\text { Craniossinostose } \\
\text { sindrômica }\end{array}$ & Não & $*$ & $*$ & $*$ \\
\hline F1423 & $\begin{array}{l}\text { Craniossinostose } \\
\text { sindrômica }\end{array}$ & Não & & & \\
\hline F1690.1 & $\begin{array}{l}\text { Craniossinostose } \\
\text { sindrômica }\end{array}$ & Não & $*$ & $*$ & $*$ \\
\hline F1699.2 & Saethre-Chotzen & Não & $*$ & $*$ & $*$ \\
\hline F1714.1 & Saethre-Chotzen & Pro136Arg & $\begin{array}{c}\mathrm{T} \\
\mathrm{WI} \\
\mathrm{ST} \\
1\end{array}$ & nova & 1 \\
\hline F1715.1 & Saethre-Chotzen & Não & $*$ & $*$ & $*$ \\
\hline F1725.1 & Crouzon & Cys278 Phe & $\begin{array}{c}\mathrm{FG} \\
\mathrm{FR} \\
2\end{array}$ & Kan et. al 2002 & 1 \\
\hline F1749.1 & Crouzon & Pro250Arg & $\begin{array}{c}\mathrm{FG} \\
\mathrm{FR} \\
3\end{array}$ & Passos-Bueno et al. 1999 & 2 \\
\hline F1764.1 & Crouzon & Cys342Ser & $\begin{array}{l}\overline{F G} \\
F R\end{array}$ & Kan et. al 2002 & 1 \\
\hline
\end{tabular}




\begin{tabular}{|c|c|c|c|c|c|}
\hline & & & 2 & & \\
\hline F1780.1 & Crouzon & Não & $*$ & * & * \\
\hline F1781.1 & Crouzon & Não & * & * & * \\
\hline F1790.1 & Saethre-Chotzen & Leu159Pro & $\begin{array}{c}\mathrm{T} \\
\mathrm{WI} \\
\mathrm{ST} \\
1\end{array}$ & nova & 3 \\
\hline F1791.1 & Plagiocefalia & Não & $*$ & $*$ & $*$ \\
\hline F1832.2 & Pfeiffer & Try290Cys & $\begin{array}{c}\mathrm{FG} \\
\mathrm{FR} \\
2\end{array}$ & Kan et. al 2002 & 1 \\
\hline F1853.1 & Crouzon & Cys342Arg & FGFR2 & Kan et. al 2002 & 1 \\
\hline F1854.1 & Crouzon & Tys281Cys & $\begin{array}{c}F \\
G \\
F R \\
2\end{array}$ & Kan et. al 2002 & 4 \\
\hline F1861.1 & Saethre-Chotzen & $-18 \mathrm{C}>\mathrm{A}$ & TWIST1 & nova & 3 \\
\hline F1852.1 & Muenke & Pro250Arg & FGFR3 & Passos-Bueno et al. 1999 & 1 \\
\hline F1909 & $\begin{array}{l}\text { Craniossinostose } \\
\text { sindrômica }\end{array}$ & Não & & & $*$ \\
\hline F1932.1 & \begin{tabular}{|l|} 
Pfeiffer \\
\end{tabular} & Não & & & \\
\hline F1943 & $\begin{array}{l}\text { Craniossinostose } \\
\text { sindrômica }\end{array}$ & Não & & & \\
\hline F1970 & Trigonocefalia & Não & & & \\
\hline F1978.1 & Crouzon & Pro250Arg & & Passos-Bueno et al. 1999 & \\
\hline F1986 & $\begin{array}{l}\text { Craniossinostose } \\
\text { sindrômica }\end{array}$ & Não & & & \\
\hline F2013.1 & Saethre-Chotzen & Gly36X & & Kress eta 1.2005 & \\
\hline F2038.1 & $\begin{array}{l}\text { Craniossinostose } \\
\text { sindrômica }\end{array}$ & Não & & & \\
\hline
\end{tabular}


Parte 3. Termo de consentimento e livre esclarecido

\section{Universidade de São Paulo}

Instituto de Biociências

\section{TERMO DE CONSENTIMENTO LIVRE E ESCLARECIDO}

ESTUDO: Estudo Molecular de Craniossinostoses

Você está sendo convidado a participar do projeto de pesquisa acima citado. O documento abaixo contém todas as informações necessárias sobre a pesquisa que estamos fazendo. Se concordar, o documento será assinado e só então daremos início à pesquisa. Sua colaboração neste estudo será de grande importância para nós, mas se desistir a qualquer momento, isso não causará nenhum prejuízo a você. 
$\mathrm{Eu}$ portador da cédula de

identidade e inscrito no $\mathrm{CPF} / \mathrm{MF}$

nascido(a) em , abaixo assinado (a), concordo de livre e espontânea vontade

participar como voluntário(a) do estudo "Estudo molecular e de expressão gênica em pacientes com Craniossinostoses ", declaro que obtive todas informações necessárias e fui esclarecido(a) de todas as dúvidas apresentadas.

Estou ciente de que:

I) O estudo se faz necessário para que possam descobrir as possíveis causas da doença denominada “Craniossinostoses”.

II) ( ) Será feita pelo menos 1 coletas de $10 \mathrm{ml}$ de sangue.

( ) Será feita coleta de material de mucosa bucal.

( ) Será feita coleta de pequeno fragmento de tecido ósseo, que normalmente seria descartado ao longo da cirurgia

III) Essas coletas serão feitas apenas para este estudo e em nada influenciarão o meu tratamento ; não vai me curar ; não vai me causar nenhum problema, exceto o pequeno incômodo de dor no caso de coleta de sangue ( introdução da agulha para retirada do sangue)

IV) A participação neste projeto não tem objetivo de se submeter a um tratamento terapêutico e será sem custo algum para mim;

V) Os resultados obtidos durante este ensaio serão mantidos em sigilo, mas concordo que sejam divulgados em publicações científicas, desde que meus dados pessoais não sejam mencionados;

VI) Caso eu deseje, poderei tomar conhecimento dos resultados ao final desta pesquisa

( ) Desejo conhecer os resultados desta pesquisa.

( ) Não desejo conhecer os resultados desta pesquisa.

VII) Esse material ou os resultados provenientes dos estudos iniciais serão aproveitados em estudos futuros, para finalidade de investigação científica. 
Responsável pelo paciente:

Telefone para contato:

Responsáveis pelo projeto:

Prof $^{\mathrm{a}} \mathrm{Dr}^{\mathrm{a}}$ Maria Rita Passos-Bueno

Telefone: (11) 3091-9910

Nélio Alessandro J. Oliveira

\section{ANEXO III}

Condições de PCR dos genes FGFR1 exon5, FGFR2 IIIa, FGFR2 IIIc, FGFR3 exon7, TWIST1 fragmento 1 e TWIST fragmento 2.

Reação para amplicons FGFR1 exon5, FGFR2 IIIa e IIIc

\begin{tabular}{|l|c|}
\hline Reagentes & 1 Reação \\
\hline Buffer 10x Amersham & $2,5 \mu l$ \\
\hline dNTP 2,5mM & $2,0 \mu 1$ \\
\hline Primer F 20mM & $1,00 \mu 1$ \\
\hline Primer R 20mM & $1,00 \mu 1$ \\
\hline Taq 5U/ $\mu$ l Amersham & $0,15 \mu 1$ \\
\hline
\end{tabular}




\begin{tabular}{|l|c|}
\hline $\mathrm{H}_{2} 0$ milliQ & $16,85 \mu \mathrm{l}$ \\
\hline Total & $23 \mu \mathrm{l}(+2 \mu \mathrm{l}$ DNA 50ng $/ \mu \mathrm{l})$ \\
\hline
\end{tabular}

Reação para amplicons FGFR3 exon7,TWIST1 fragmento 1 e fragmento 2

\begin{tabular}{|l|c|}
\hline Reagentes & 1 Reação \\
\hline DMSO 10\% & $2,5 \mu \mathrm{l}$ \\
\hline Buffer 10x Amersham & $2,5 \mu \mathrm{l}$ \\
\hline dNTP 2,5mM & $2,0 \mu \mathrm{l}$ \\
\hline Primer F 20mM & $1,00 \mu \mathrm{l}$ \\
\hline Primer R 20mM & $1,00 \mu \mathrm{l}$ \\
\hline Taq 5U/ $\mu$ Amersham & $0,15 \mu 1$ \\
\hline $\mathrm{H}_{2} 0$ milliQ & $13,85 \mu \mathrm{l}$ \\
\hline Total & $23 \mu \mathrm{l}(+2 \mu 1$ DNA 50ng $/ \mu \mathrm{l})$ \\
\hline
\end{tabular}

$\Rightarrow$ Programa para amplificação: FGFR2 IIIA

- $95^{\circ} \mathrm{C}-2 \mathrm{~min}$

$-94^{\circ} \mathrm{C}-20 \mathrm{seg}$

$69^{\circ} \mathrm{C}-60 \mathrm{seg}-0,5$ a cada ciclo $15 \mathrm{x}$

$72^{\circ} \mathrm{C}-1 \mathrm{~min}$

$-94^{\circ} \mathrm{C}-20 \mathrm{seg}$

$\left.-62^{\circ} \mathrm{C}-20 \mathrm{seg}\right\} 20 \mathrm{X}$

$72^{\circ} \mathrm{C}-60 \mathrm{seg}$

$72^{\circ} \mathrm{C}-6 \mathrm{~min}$

$10^{\circ} \mathrm{C} \infty$ 
$\Rightarrow$ Programa para amplificação: FGFR2 IIIC FGFRs

$-95^{\circ} \mathrm{C}-4 \mathrm{~min}$

$-95^{\circ} \mathrm{C}-40 \mathrm{seg}$

$\left.-58^{\circ} \mathrm{C}-40 \mathrm{seg}\right\} 35 \mathrm{X}$

$-72^{\circ} \mathrm{C}-40 \mathrm{seg}$

$-72{ }^{\circ} \mathrm{C}-6 \mathrm{~min}$

$-10^{\circ} \mathrm{C} \infty$

$\Rightarrow$ Programa para amplificação: FGFR3 3 TWIST1

$-94^{\circ} \mathrm{C}-5 \mathrm{~min}$

$-94^{\circ} \mathrm{C}-45 \mathrm{seg}$

$-62^{\circ} \mathrm{C}-45 \mathrm{seg}$ $35 \mathrm{X}$

$-72^{\circ} \mathrm{C}-1 \mathrm{~min}$

$-72{ }^{\circ} \mathrm{C}-10 \mathrm{~min}$

$-10^{\circ} \mathrm{C} \infty$

$\Rightarrow$ Programa de Heteroduplex:

$-95^{\circ} \mathrm{C}-4 \min$

$--70^{\circ} \mathrm{C}-$

- $-0,3$ por $10 \mathrm{seg}$

$-04^{\circ} \mathrm{C} \infty$ 